\title{
An electron microscopic study of the epithelium of normal human sigmoid colonic mucosa
}

\author{
FRED E. PITTMAN AND JOAN C. PITTMAN \\ From the University Department of Medicine, Queen Elizabeth Hospital, Birmingham
}

EDITORIAL COMMENT This is a basic study of electron microscopic appearances of normal human colonic epithelium. The findings enable an interesting comparison to be made with jejunal epithelium and provide further data for a discussion of the filamentous network which extends from the surface of microvilli.

The mucosal lining of the human large bowel has received little attention from electron microscopists. Ultrastructural studies of this tissue have been limited primarily to goblet cells in the mouse and rat (Shearman and Muir, 1960; Florey, 1960; Hampton, 1960; Hayward and Johnston, 1961; Freeman, 1962; Hollmann, 1963; Lane, Caro, Otero-Vilardebó, and Godman, 1964). This study was therefore undertaken to examine the ultrastructural morphology of normal human colonic mucosa.

\section{MATERIALS AND METHODS}

Two specimens of mucosa were obtained from the sigmoid colon with biopsy forceps at the time of sigmoidoscopy from 13 male and four female adults, none of whom had evidence of disease of the large bowel. Three had bled previously from the upper gastrointestinal tract; the remaining 14 subjects had no known bowel disease. Phosphate 'clean-out' enemas were given to seven subjects one hour before the biopsies were taken. All of the subjects ate a normal breakfast approximately two hours before the procedure. The sigmoidoscopic appearances of the rectal and sigmoid colonic mucosa were normal in each instance.

One mucosal specimen from each subject was flattened, cut surface down, onto cardboard, fixed in iced $10 \%$ formal saline, and embedded 'on edge' in paraffin. Multiple sections of the 17 specimens were stained with haematoxylin and eosin, periodic acid-Schiff (P.A.S.), and Van Gieson's picrofuchsin. Light microscopy of all these specimens was normal according to the criteria of Flick, Voegtlin, and Rubin (1962). The second mucosal specimen was also flattened, cut surface down, onto cardboard, fixed for three hours in iced glutaraldehyde, washed in phosphate-buffered sucrose (five changes over two-and-a-half hours), and stored in buffered sucrose at $4^{\circ} \mathrm{C}$. for no longer than 14 days (Sabatini, Bensch, and

Requests for reprints to: Fred E. Pittman, M.D., Ph.D. Department of Medicine, Tulane University, 1430, Tulane Avenue, New Orleans, La. 70112, U.S.A.
Barrnett, 1963). The specimen was cut subsequently into wedge-shaped blocks, approximately $4 \mathrm{~mm}$. long and $2 \mathrm{~mm}$. at the base. These small blocks were then fixed in buffered osmium tetroxide for three hours (Caulfield, 1957), dehydrated in increasing strengths of ethyl alcohol, and embedded in Dow epoxy resin, Lockwood's mixture no. 1 (Lockwood, 1964). The wedge-shaped blocks were embedded 'on edge' in such a way that well-orientated thick sections $(1 \mu)$ could be obtained without difficulty (Rangan, 1961; Pittman and Pittman, 1966). These sections were stained with toluidine blue (Trump, Smuckler, and Benditt, 1961), examined with a light microscope, and used to locate the area to be trimmed for thin sectioning. Thin sections $(500 \AA$ to $700 \AA)$ were cut with a diamond knife on either a Huxley Cambridge or a Porter-Blum MK-2 ultramicrotome and stained with a saturated solution of uranyl nitrate in absolute methanol followed by Millonig's lead tartrate (Millonig, 1961). Details of these preparative techniques are given elsewhere (Pittman and Pittman, 1966). The stained thin sections were examined with an AEI EM6 electron microscope. Micrographs were taken on Kodak B.10 high contrast plates.

\section{RESULTS}

The luminal surface of human sigmoid colonic mucosa is flat. Invaginations of the lining epithelium form the mucous glands or crypts of Lieberkühn (Fig. 1). The epithelial cells lining the mucous membrane are columnar and are primarily of two types, the mucus-secreting goblet cells and the principal (absorptive) cells. Occasionally, cells with characteristics of the Kultschitzky cell (argentaffin or enterochromaffin cell) are found at the base of the crypts of Lieberkühn.

GOBLET CELLS The crypts of Lieberkühn are lined almost exclusively by goblet cells. These cells, which are also found interspersed with principal cells, on the luminal surface, are the dominant epithelial cell 
type of the mucosa. Studies with tritiated thymidine and microradiography have indicated that colonic epithelial cells in man, as in the mouse, proliferate in the lower two-thirds of the crypts of Lieberkühn and migrate to the luminal surface during a period estimated to be between four and eight days (Cole and McKalen, 1961; Lipkin, Sherlock, and Bell, 1963; MacDonald, Trier, and Everett, 1964).

In the present study goblet cells were examined at all levels of the crypts and at the luminal surface. The ultrastructural appearances of these cells are similar to those described in the mouse and rat (Shearman and Muir, 1960; Florey, 1960; Hampton, 1960; Hayward and Johnston, 1961; Freeman, 1962; Hollmann, 1963; Lane et al., 1964). At the base of the crypts are found undifferentiated cells and goblet cells in the earliest phase of mucus production (Fig. 2). The nuclei of these cells are centrally located and are surrounded by dense accumulations of membranes and granules. Some of the granules are attached to membranes (Fig. 3), and are thought to contain ribonucleoprotein (Palade, 1958). Sjöstrand (1964) has suggested the term 'alpha-cytomembranes' to distinguish these granular membranes from others within the cytoplasm. In the basilar cytoplasm of more mature goblet cells there are, in addition, mitochondria, vesicles, and granular material which is not attached to membranes (Fig. 4). In the paraand supranuclear areas there are smooth, flattened or 'stacked' membranes and vesicles which are the Golgi apparatus of the goblet cell (Dalton, 1951; Florey, 1960). The ultrastructural appearances suggest that the Golgi membranes form sacs or vesicles which are distended progressively with mucin as they move towards the apical portion of the cell (Figs. 5a and 5b). Support for this interpretation has been provided by a study of the incorporation of ${ }^{35} \mathrm{~S}$ into mucin in goblet cells of rat colonic mucosa (Lane et al., 1964). It was found that following injection of ${ }^{35} \mathrm{~S}$, radioactivity was associated initially with the 'stacked' membranes of the Golgi apparatus, next with the membranes surrounding mucin droplets within the goblet, and finally with the secreted mucin in the lumen of the crypts.

The nuclei and cytoplasm of the more mature goblet cells found in the upper two-thirds of the crypts are pressed basally and laterally by the distended goblets, which eventually burst through the apex of the cell (Figs. 6a and 6b). Many mitochondria, with their outer membranes closely associated with those of mucin droplets, are present in the cytoplasm which surrounds the goblet. Within the goblet, individual mucin droplets are surrounded by cytoplasm which is continuous in a number of places with that around the goblet. Each mucin droplet contains a meshwork of interconnecting filaments which, on high magnification, is seen to be composed of very electron-dense spherical units associated with filamentous material (Fig. 7).

The lateral wall of the goblet cell is a membrane composed of a single layer of electron-dense spherical units. This membrane interdigitates with the membrane of the adjacent cell (Fig. 8). The basilar cell wall is a single-layered membrane also (Fig. 9). There is filamentous material beneath the basilar membrane (Fig. 9).

The nucleus of the mature goblet cell has ultrastructural appearances similar to those of nuclei of other mammalian cells (Wischnitzer, 1960). An envelope or perinuclear cistern limits the nucleus (Fig. 10). Both the inner and outer membranes of the cistern appear to be composed of closely approximated granular particles. There are openings or pores in the nuclear envelope where the granular cytoplasm surrounding the nucleus communicates with the nucleoplasm, and many mitochrondria are adjacent to the outer membrane of the envelope (Fig. 10). The nucleus and supranuclear Golgi membranes of the goblet cells at an early phase of the production of mucus are surrounded by an area of cytoplasm with greater electron density than that in the rest of the cell. This dense cytoplasm is enclosed by a smooth membrane (Fig. 4).

The nucleus contains at its periphery and interspersed throughout the interior finely granular material of greater electron density than the remainder of the nucleoplasm (Figs. 4 and 10), and this electron-dense material is thought to be the chromatin of the cell and to be rich in DNA (Moses, 1964). One or more nucleoli are readily distinguished within the nucleoplasm as spherical structures of compact electron-dense granules with central areas of less electron density (Fig. 4).

Rudimentary microvilli are present at the apical surface of goblet cells in the lower portions of the crypts (Fig. 11). Goblet cells situated in the upper portion of the crypts and on the luminal surface of the mucosa appear to have apical cytoplasm and microvillous borders indistinguishable from those of principal cells. However, it is often impossible to determine whether the cytoplasm and microvillous border above a goblet belong to the goblet cell or to an adjacent principal cell.

In some of the specimens spaces were observed along the lateral walls of cells lining the crypts (Fig. 12) and may represent channels of fluid and electrolyte absorption.

PRINCIPAL CELLS The principal cells are columnar epithelial cells with a basilar or centrally located nucleus which has ultrastructural appearances identical with those of the goblet cell nucleus. The 
principal cells are the major cell type lining the lumen of the colon, and they are also found interspersed with goblet cells in the crypts (Figs. 13 and 14). These cells are thought to function primarily to absorb water and electrolytes from the contents of the bowel, and their luminal surface is composed of microvilli, the cylindrical cell processes common to most absorptive epithelium (Fig. 15). The majority of well-orientated microvilli found in the upper portions of the crypts and on the bowel surface measure $2.0 \mu \pm 0.5 \mu$ in length and $0.25 \mu \pm 0.02 \mu$ in width. ${ }^{1}$ Occasionally, however, apparently well-orientated microvilli as short as $\mathbf{0 . 2} \mu$ are observed (Fig. 15). The intermicrovillous spaces vary considerably, from $600 \AA$ to $1 \cdot 33 \mu$.

At relatively low magnification (e.g., 20,000) the microvilli appear to be bounded by two continuous membranes. High magnification reveals that the membranes, separated by a space approximately $100 \AA$ wide, are not continuous and are composed of intensely electron-dense spherical units approximately $375 \AA$ in diameter, linked to each other by less electron-dense filamentous material approximately $190 \AA$ thick. The membranes in section thus have the appearance of strings of beads (Fig. 16). In some areas, especially on the outer membranes, the spherical units are spaced at variable distances and the filamentous links appear to be missing, leaving openings up to $100 \AA$ wide (Fig. 17). Within the interior of each microvillus are a number of longitudinally orientated chains of material which appear almost identical with the material which forms the outer membranes. The spherical units are, however, more widely separated in these interior chains than on the outer membranes (Fig. 16). The chains within the microvilli extend into the apical cytoplasm (Fig. 16), an area called the 'clear zone' because of the absence of mitochondria and cytoplasmic membranes (Fig. 18). With the exception of the area directly beneath the microvilli, no orderly arrangement of spherical units and filamentous material is noted within the clear zone.

A dense network of filaments, which resemble in composition the limiting membranes and interior chains of the microvilli, extends from the entire surface of the principal cell (Fig. 15). The composition of this network of filaments is also somewhat similar to that of mucin droplets (Fig. 7). The filamentous coating protrudes, on the average, a distance of $2 \cdot 0 \mu$ from the tips of microvilli. At the sides and bases of microvilli the filaments are continuous with those of adjacent microvillous surfaces (Fig. 16).

A striking finding is the extent of vesicle formation

${ }^{1}$ These and subsequent measurements were made from enlargements of the photographic plates. An optical micrometer was used to measure objects and spaces less than $1.0 \mathrm{~cm}$. in the cytoplasm of principal cells. The limiting membranes of the vesicles resemble the surface membranes of the principal cell. Within the vesicles is a meshwork of filaments similar to that which coats the microvilli (Fig. 16). Vesicles containing this material are present within the cytoplasm at all levels of the cell along its longitudinal axis (Fig. 18). Some of the vesicles communicate with the surface membranes of the cell at the bases of microvilli (Fig. 19).

Numerous round structures which measure $600 \AA$ $\pm 200 \AA$ in diameter are present within the microvillous border (Figs. 15 and 16), and appear to arise from the 'degeneration' of microvilli (Figs. 16 and 20). On high magnification these structures appear to be composed of the same basic units found within the microvilli and are coated with filaments which extend from their surfaces and join filaments of adjacent microvilli (Fig. 16). The vesicles described previously frequently contain round structures which resemble those present within the microvillous border (Fig. 21).

COMPARISON OF THE MICROVILLOUS BORDERS OF NORMAL HUMAN COLONIC AND JEJUNAL PRINCIPAL CELLS Jejunal mucosa was obtained with the Crosby peroral biopsy capsule (Crosby and Kugler, 1957) from two fasting individuals and processed for electron microscopy as described above. The microvilli of principal cells were found to be strikingly uniform, measuring $6.0 \mu \pm 1.0 \mu$ in length and $0.4 \mu \pm 0.05 \mu$ in width. The intermicrovillous spaces are also uniform, measuring $0.5 \mu$ to $0.6 \mu$ in width (Fig. 22). Jejunal microvilli are thus approximately three times as long and one and one half times as wide as those of colonic principal cells. There are, however, roughly the same number of microvilli per unit surface area in both types of principal cell. The depths of the clear zones of these cells are comparable $(3.0 \mu \pm 1.5 \mu)$.

The microvillous border of jejunal principal cells is similar to the colonic microvillous border in several respects: a double membrane surrounds the microvilli, interior chains extend into a clear zone, round structures are prominent within the microvillous border, and a filamentous coating protrudes from the entire limiting membrane of the microvilli (Fig. 22). This coating extends only $0.5 \mu$ beyond the tips of the microvilli and is more dense and highly interconnected than its colonic counterpart. The dimensions and spacing of the basic spherical units and filamentous links comprising all these structures differ from those of the basic components of colonic microvilli (Figs. 23a, 23b, and 23c). These and other differences are summarized in Table $I$.

It was noted previously that the mucin droplets of 


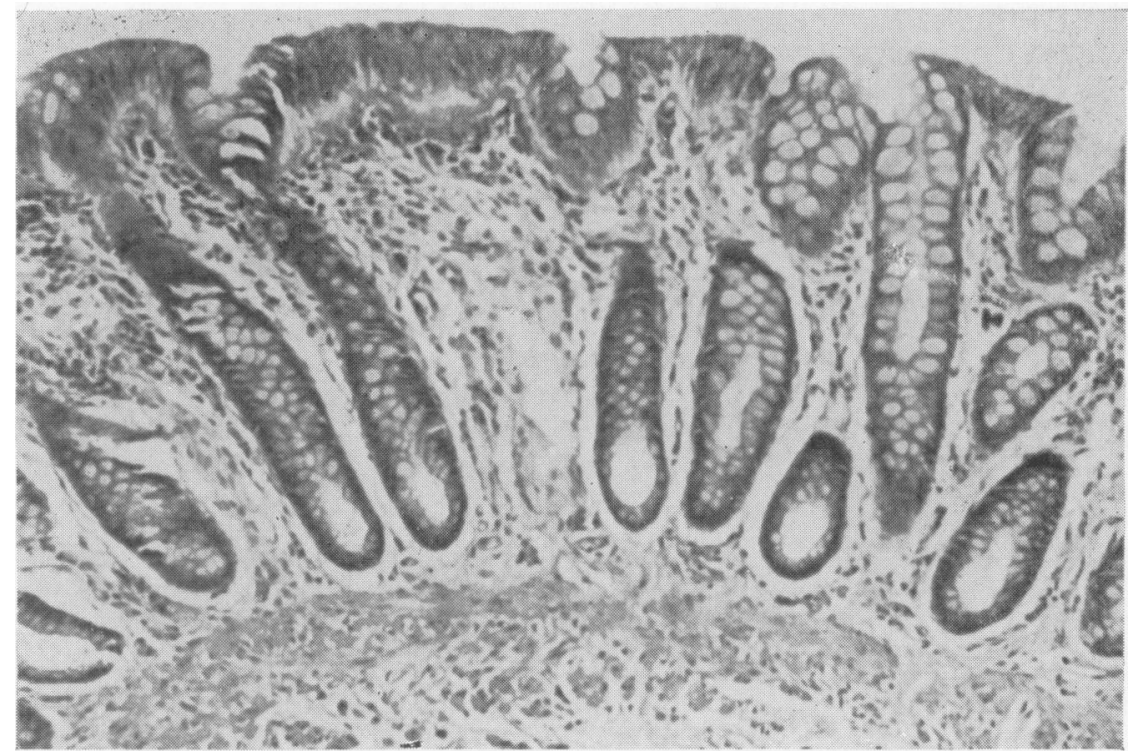

FIG. 1. Light micro-

graph. Normal human sigmoid colonic mucosa. The surface is flat.

Numerous crypts of Lieberkühn are present, formed by invaginations of the surface epithelium. The crypts are lined by goblet cells, for the most part. The luminal surface epithelium consists predominantly of principal cells (haematoxylin and eosin $\times 80$ ).

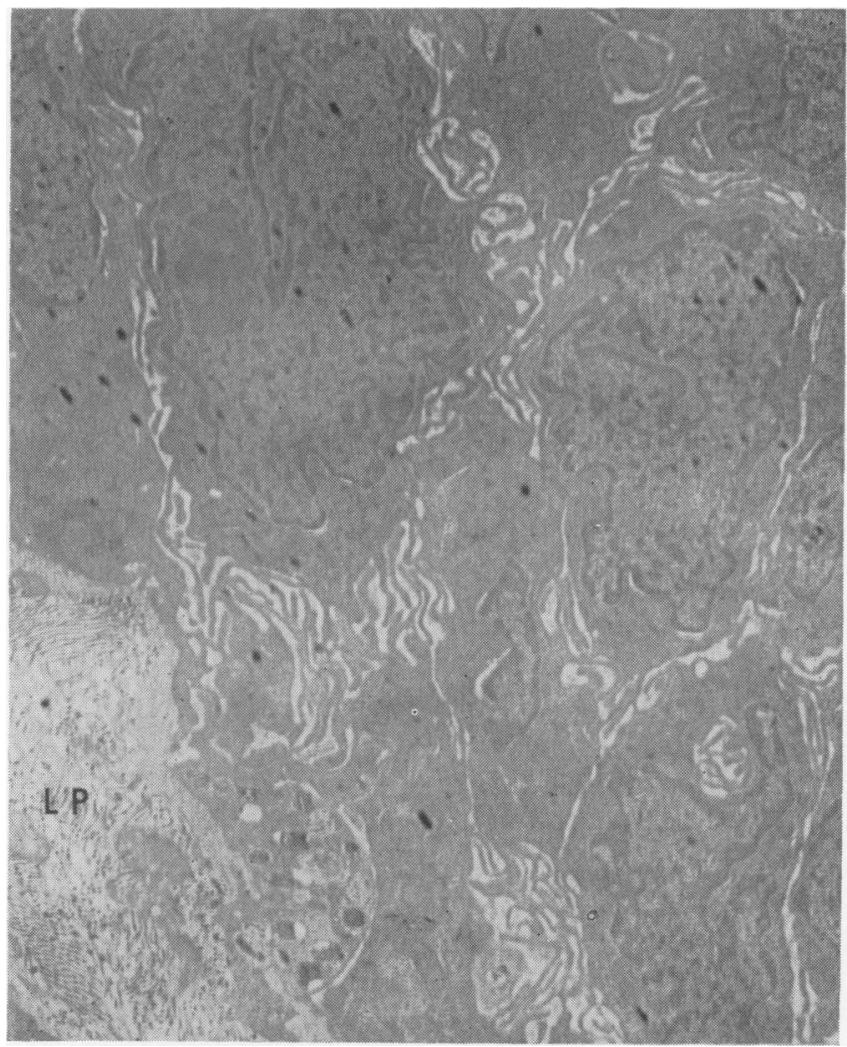

FIG. 2.

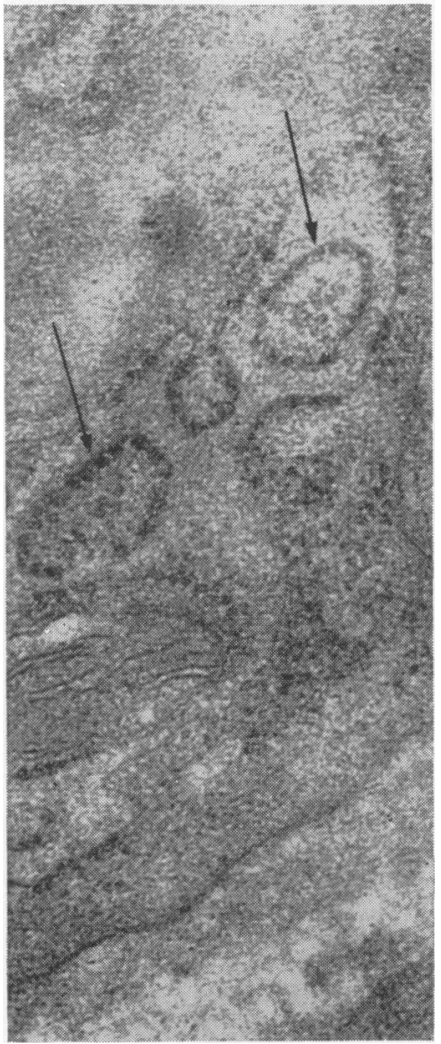

FIG. 3 .

FIG. 2. Early epithelial cell forms located at the base of a crypt. LP = lamina propria $(\times 4,500)$.

FIG. 3. Alpha-cytomembranes (arrows) in the basilar cytoplasm of a more mature goblet cell $(\times 173,000)$. 


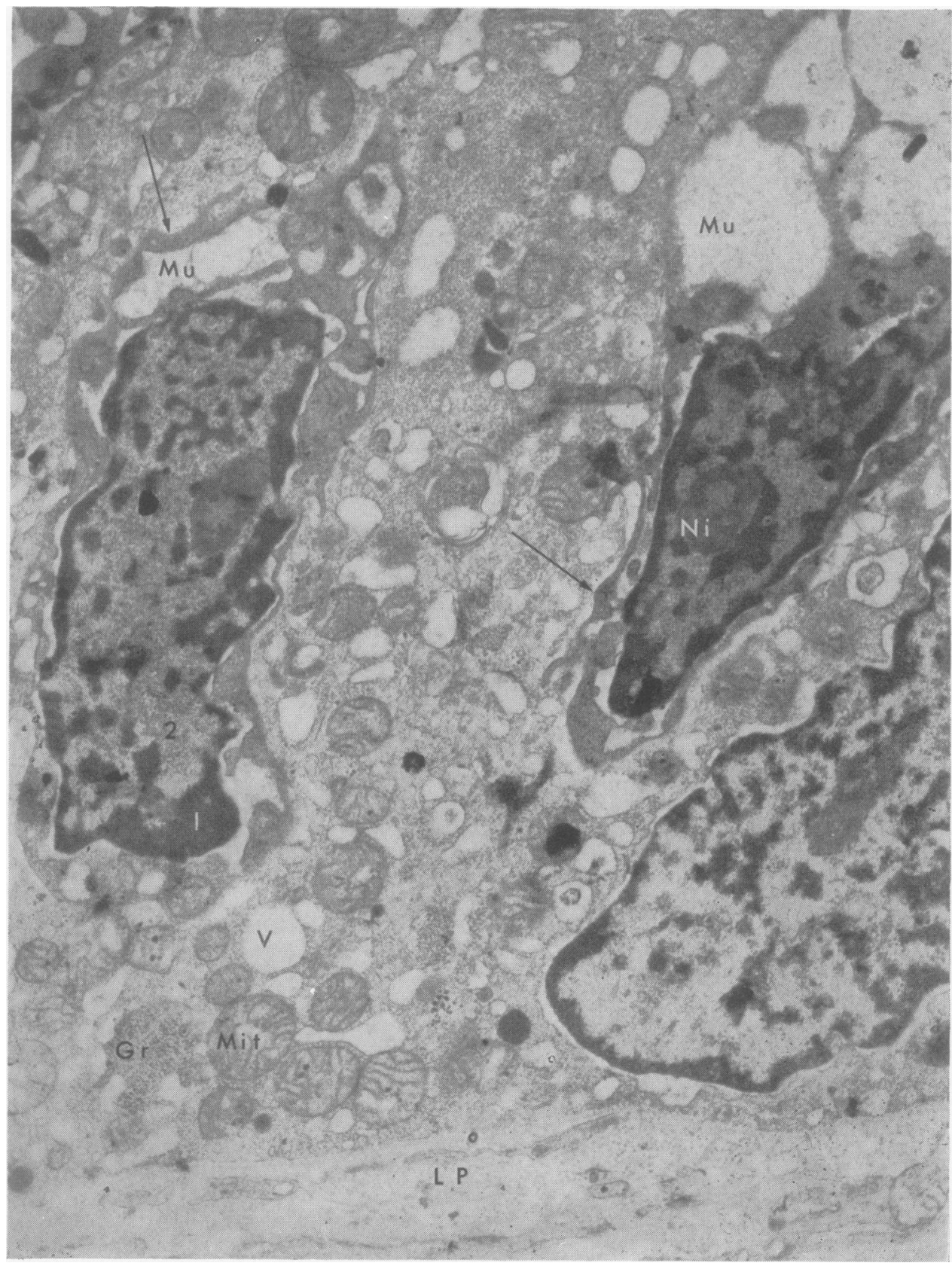

FIG. 4. Basilar cytoplasm and nuclei of goblet cells in the lower third of a crypt of Lieberkühn. Granules $(G r)$, mitochondria (Mit), and vesicles $(V)$ are prominent.Two of these cells are in an early phase of mucus secretion and the nuclei and mucin goblets $(\mathrm{Mu})$ are surrounded by granular cytoplasm (arrows) which has a greater electron density than that of the remainder of the cell. There is dark staining granular material (? chromatin-1) located chiefly at the periphery of the nucleus, but also interspersed throughout the interior. Also within the interior is less electron-dense granular material (2). One or more nucleoli (Ni) are usually seen. The nucleoli are composed of granular material and have central areas which are less electron-dense than the remainder $(\times 16,200)$. 


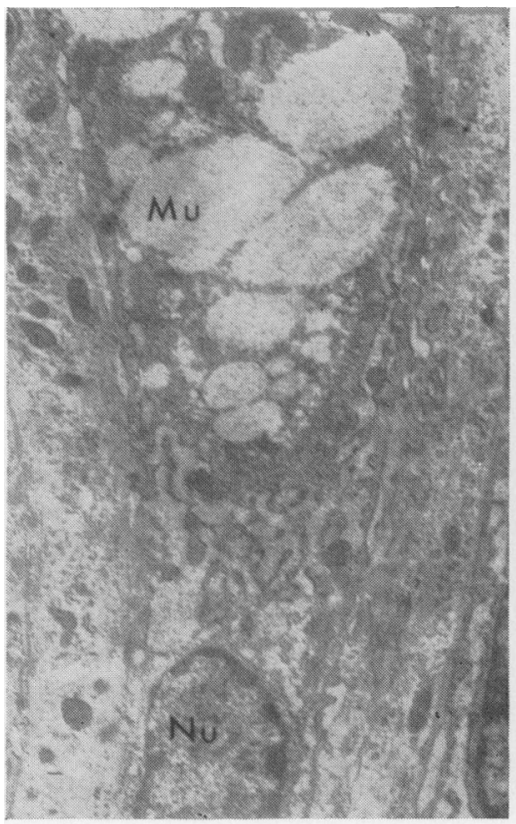

FIG. 5a.

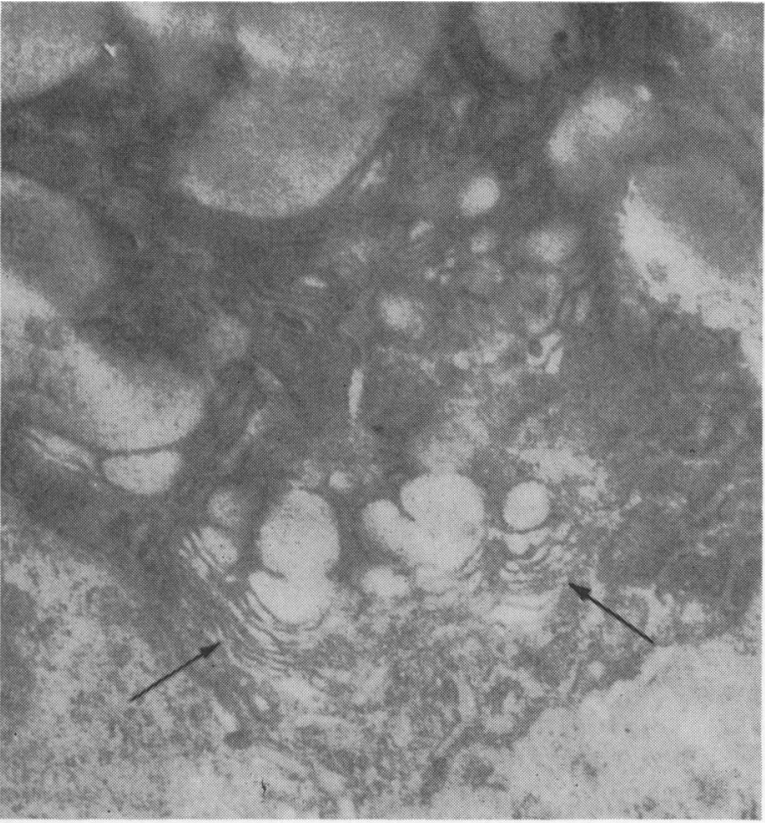

FIG. 5 b.

FIG. 5a and 5b. Mucin droplets $(\mathrm{Mu})$ arise from the supranuclear region of the goblet cell $(\mathrm{Nu}=$ nucleus $)$ $(5 a \times 4,200)$. These droplets appear to be formed from the 'stacked' membranes of the supranuclear Golgi apparatus (arrows) $(5 b \times 16,000)$.

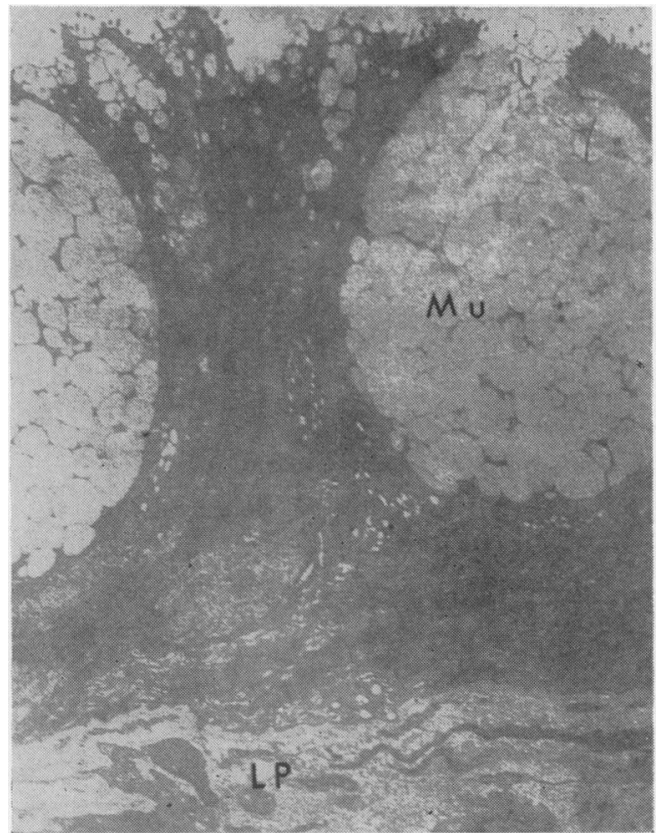

FIG. 6a.

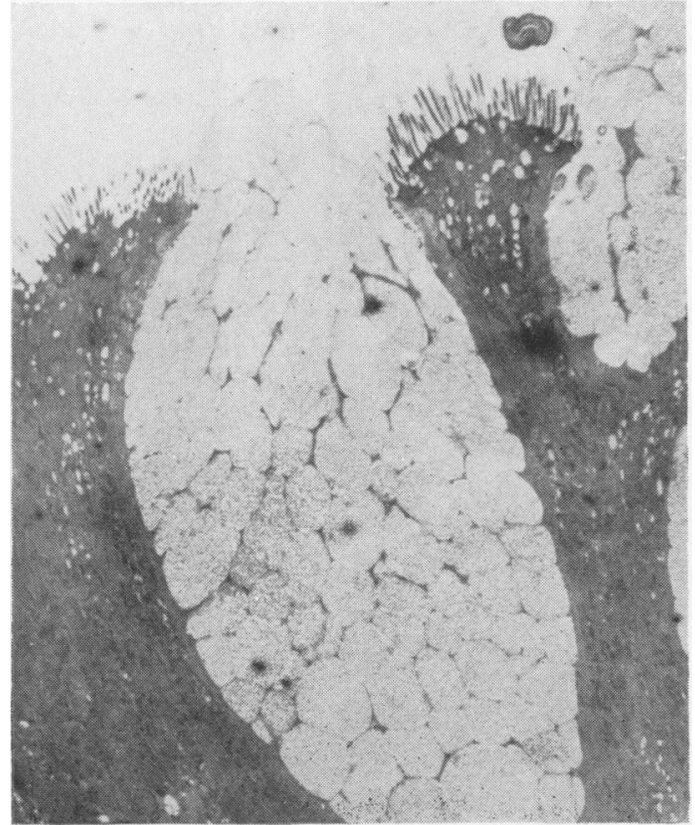

FIG. $6 \mathrm{~b}$.

FIG. 6a. Goblet cell distended with mucin droplets $(M u)$ in mid-portion of a crypt $(\times 1,500)$.

FIG. 6b. Mucin droplets in the process of extrusion from a goblet cell in the upper portion of a crypt of Lieberkühn $(\times 2,500)$. 
FIG. 7.

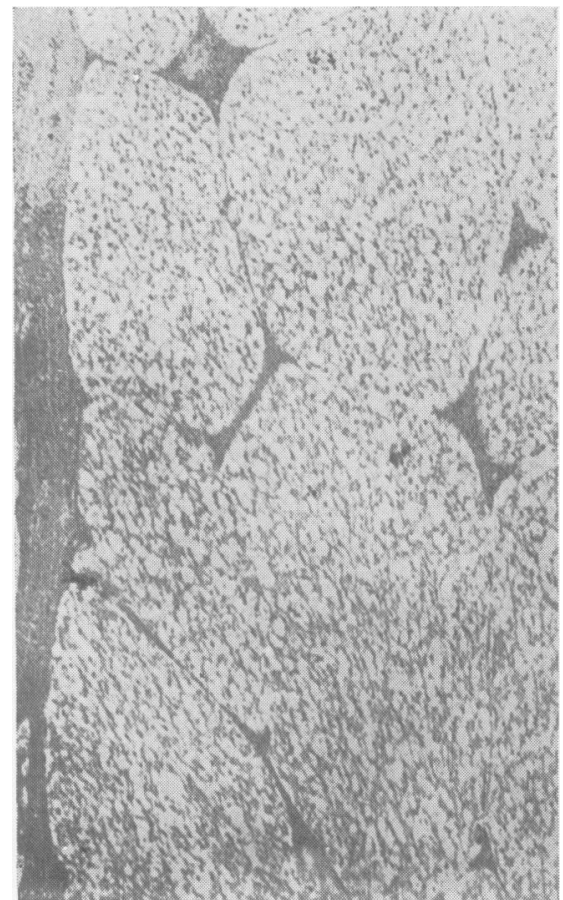

FIG. 8.

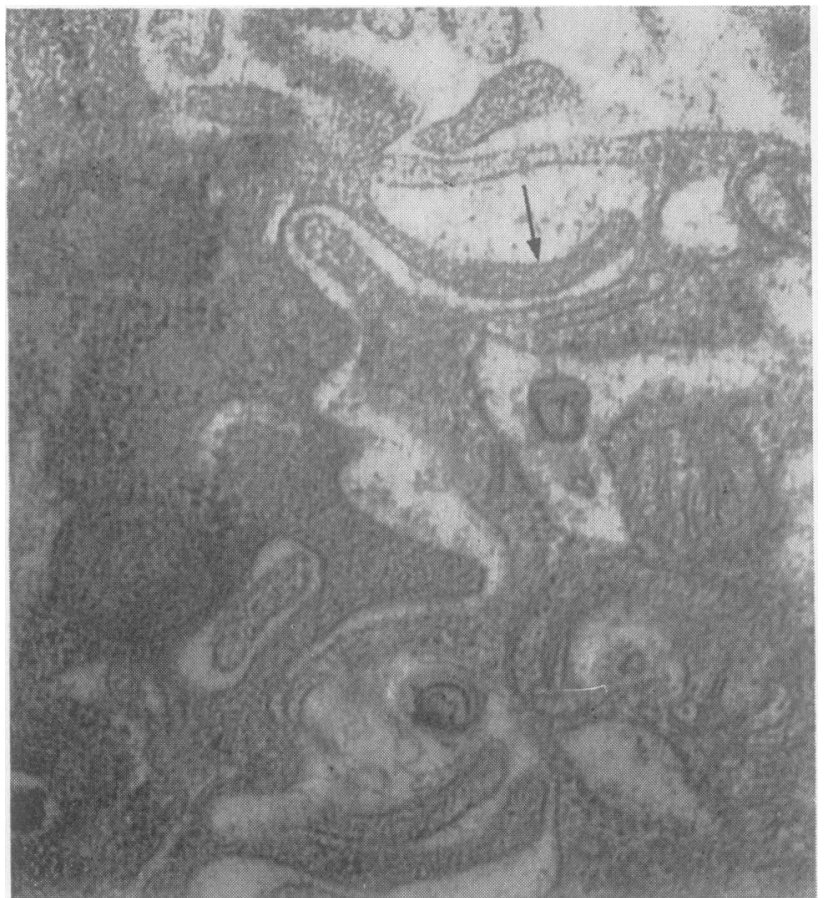

FIG. 7. Higher magnification of mucin droplets demonstrates the spherical units associated with less electron-dense filamentous material $(\times 16,200)$.

FIG. 8. The lateral cell membranes of goblet cells interdigitate with those of adjacent cells (arrow) $(\times 46,400)$.

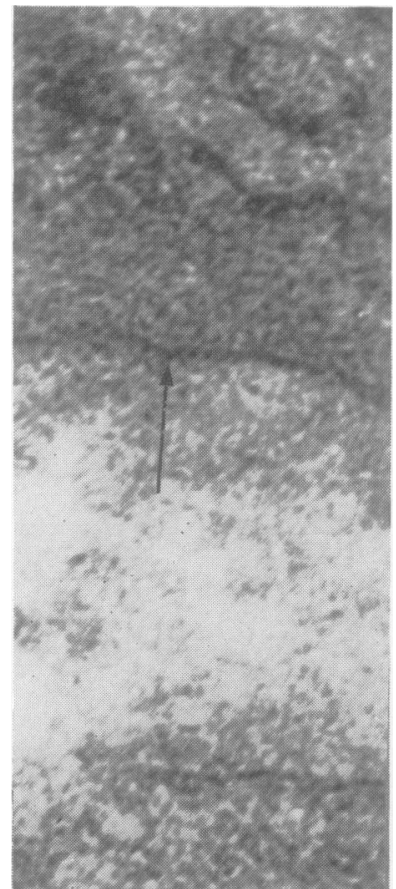

FIG. 10.

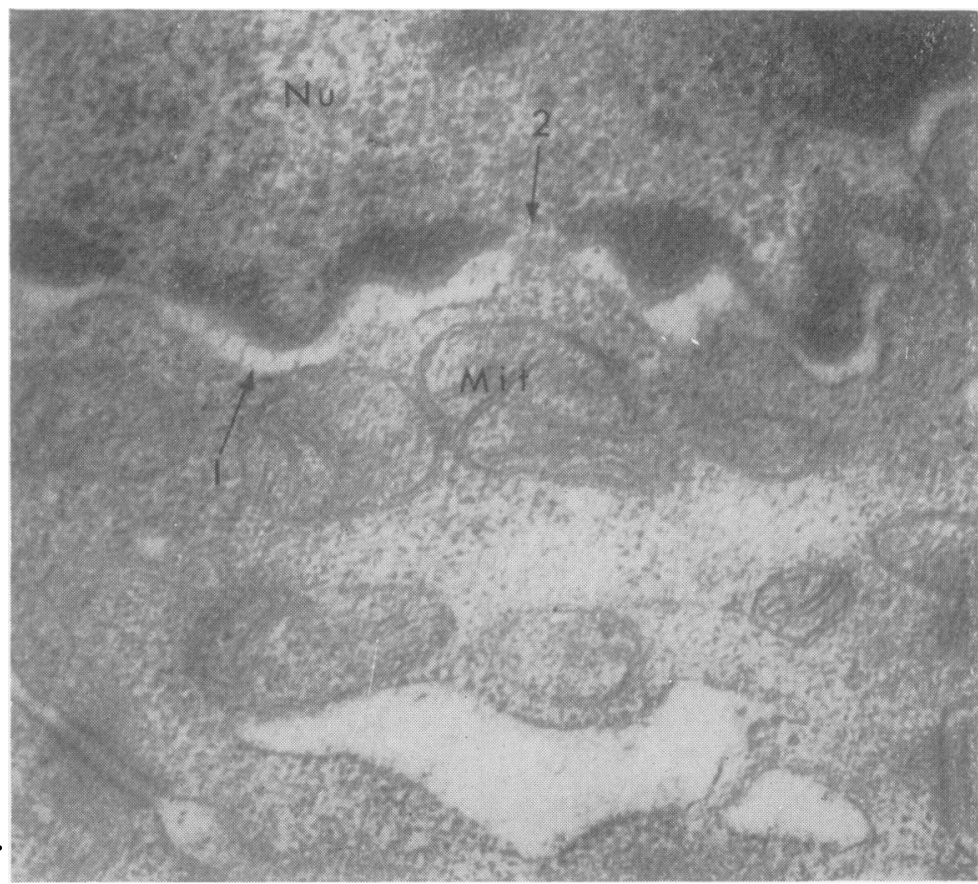

FIG. 9. The basilar membrane of the goblet cell consists of electron-dense spherical units (arrow). Beneath this membrane there is a layer of filamentous material $(\times 342 ; 500)$.

FIG. 10. Portion of a nucleus $(\mathrm{Nu})$ of goblet cell. The nucleus is limited by an envelope or perinuclear cistern (1). Filaments traverse this cisterna, and there are openings in it (2) which appear to permit free exchange of cytoplasm and the less electron-dense part of the nucleoplasm. Mitochondria (Mit) are adjacent to the other membrane of the envelope $(\times 46,400)$. 


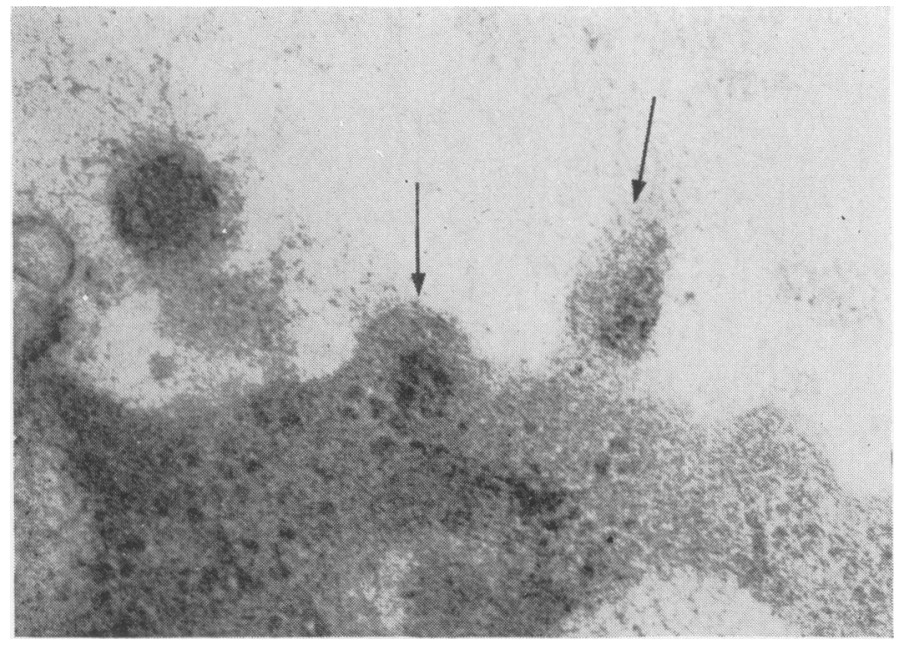

FIG. 11. Portion of the surface of a cell in the lower part of a crypt. Only rudimentary mirovilli are present (arrows) $(\times 100,000)$.

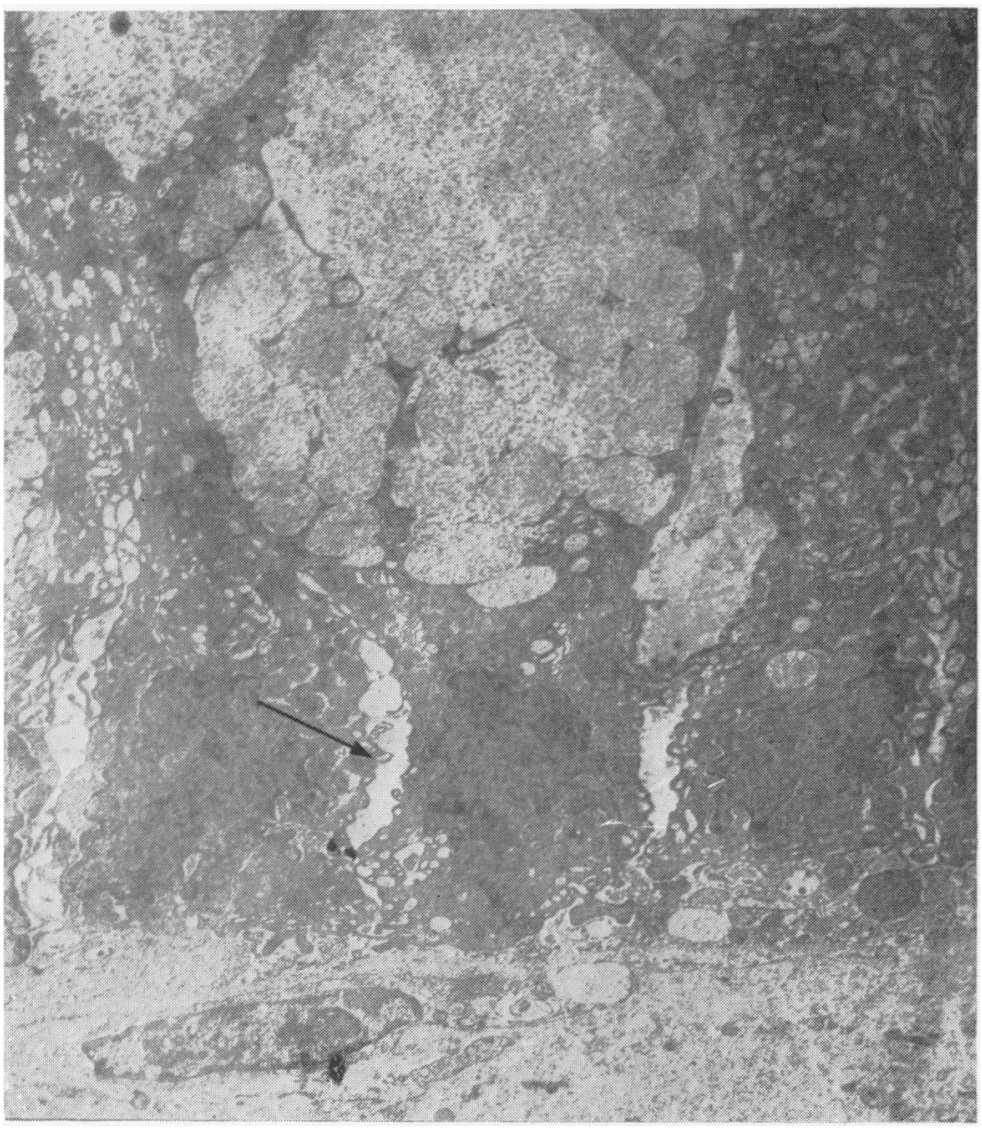

FIG. 12. Spaces along the lateral cell margins of cells lining a crypt (arrow) $(\times 3,000)$. 


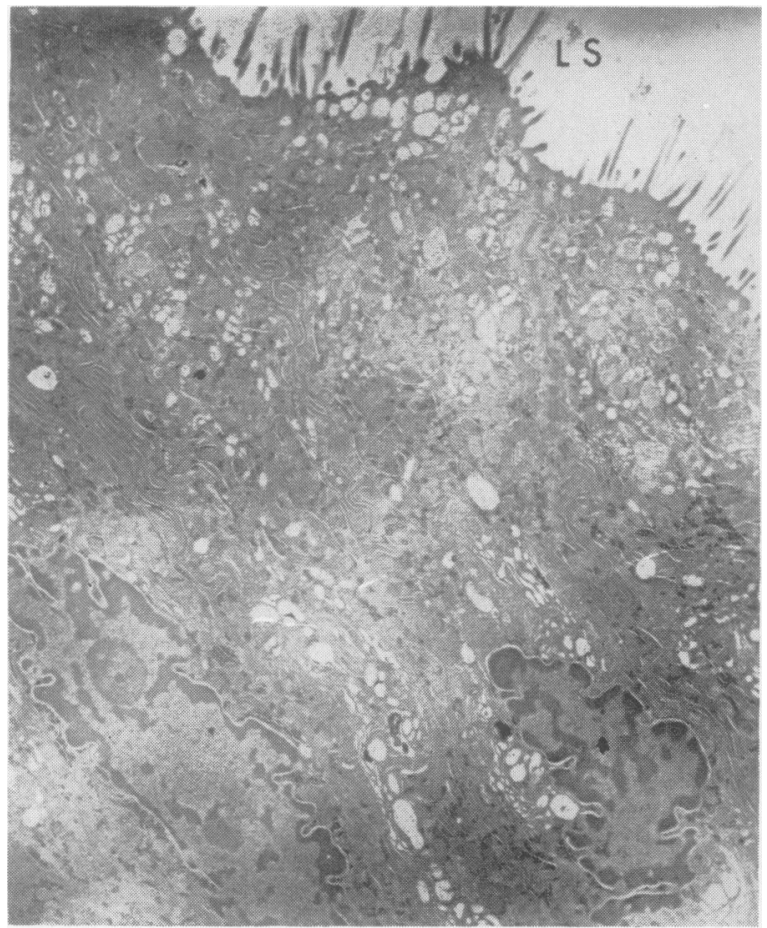

FIG. 13.

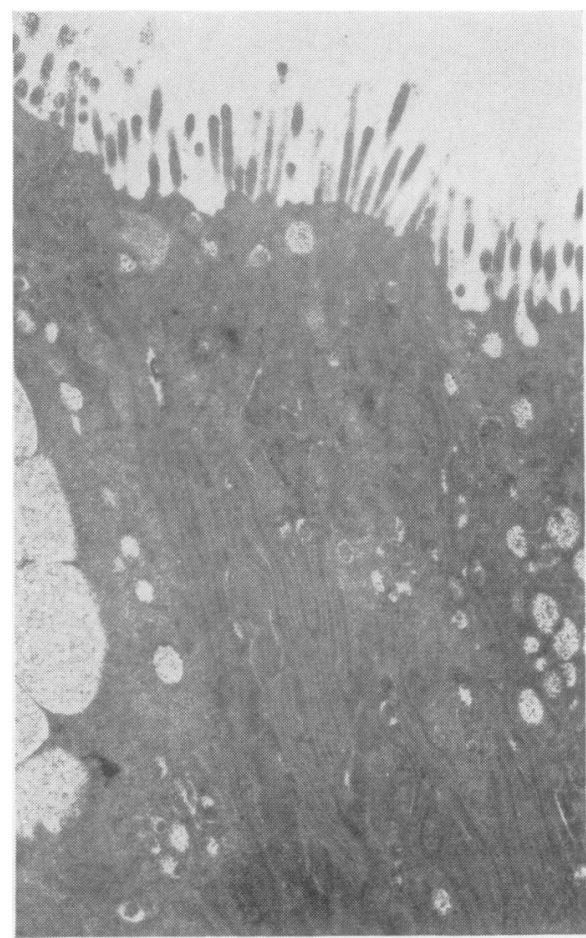

FIG. 14.

FIG. 13. Principal cells lining the luminal surface $(L S)$ of the mucosa $(\times 6,500)$.

FIG. 14. Principal cells between goblets cells in the upper portion of a crypt $(\times 12,000)$.

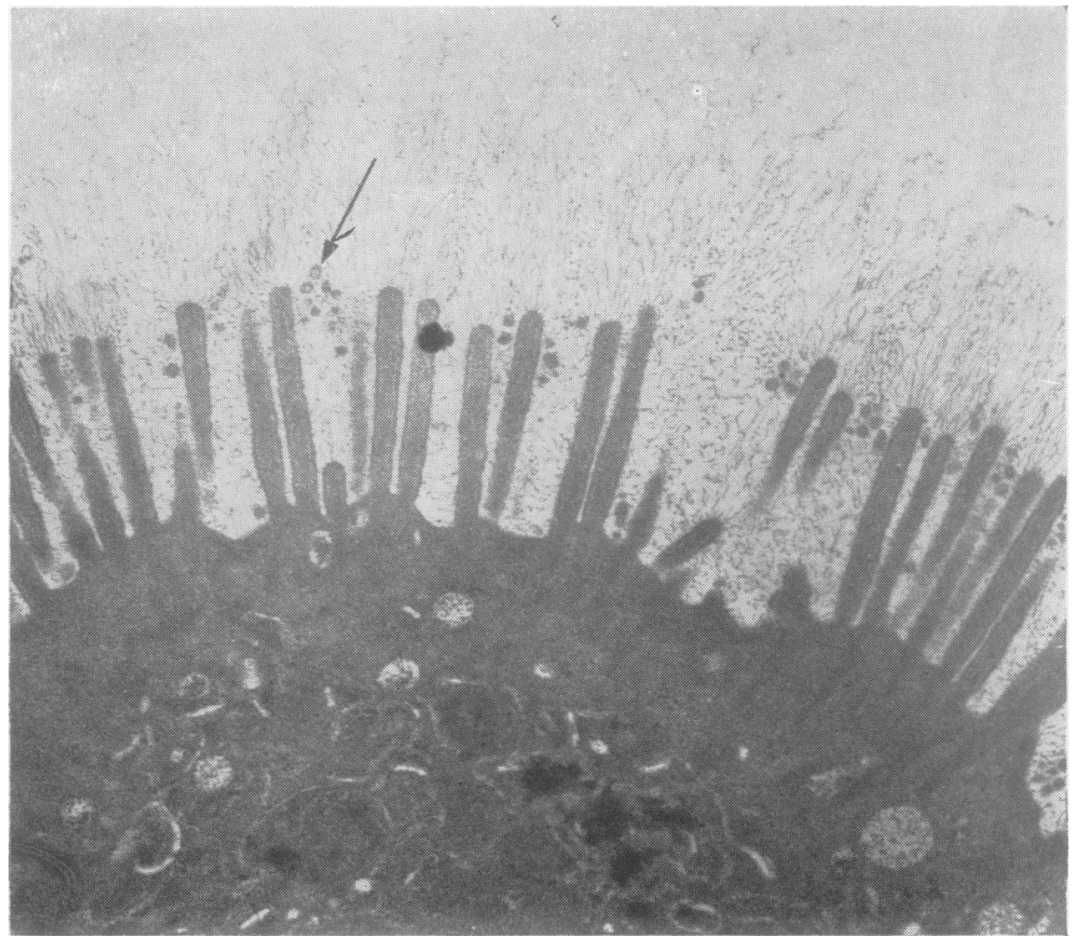

FIG. 15. Apical portion of a principal cell lining the luminal surface of sigmoid colonic mucosa. Filaments project from the surface of the microvilli and round structures (arrow) are present within the microvillous border $(\times 11,400)$. 


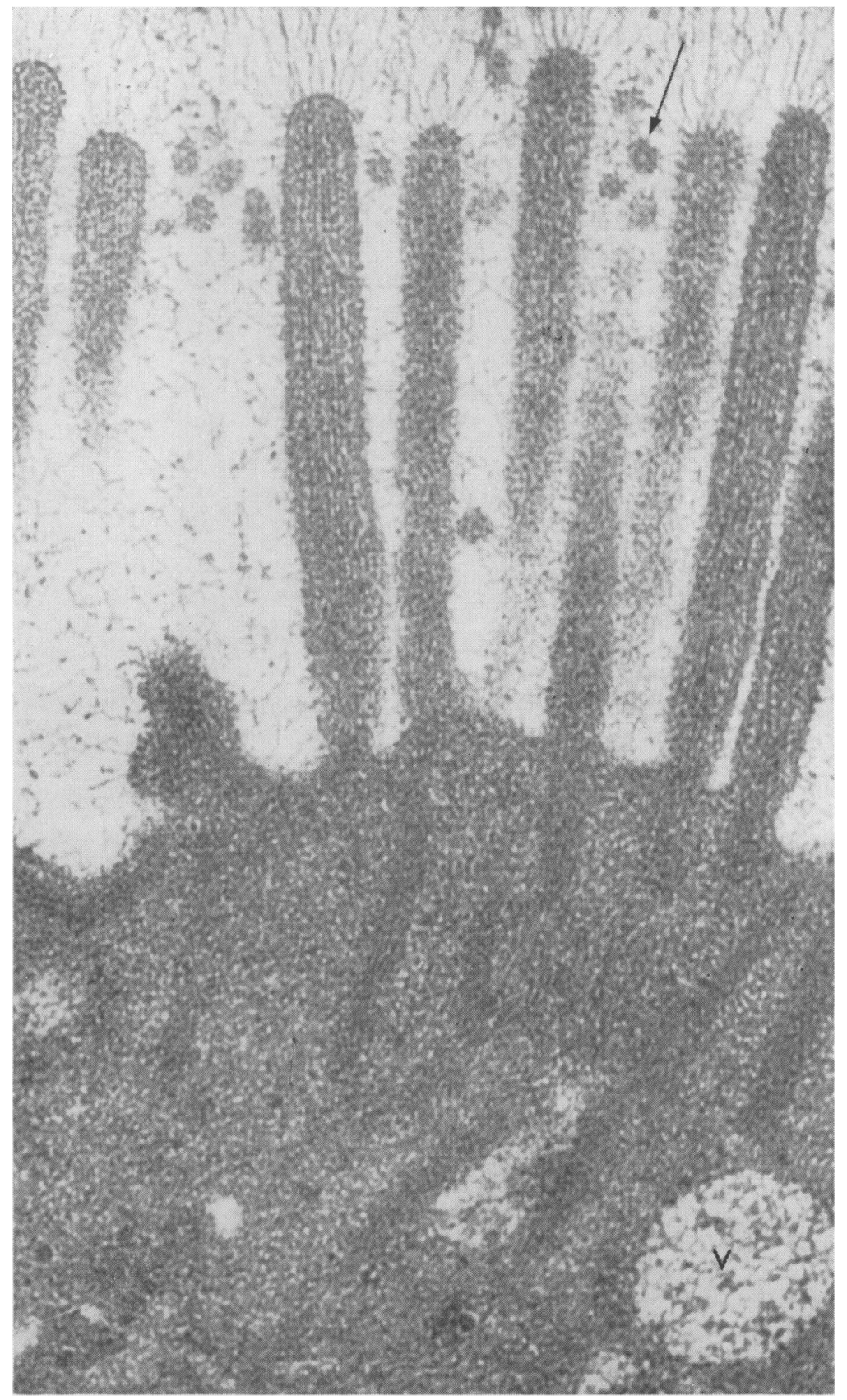

FIG. 16. Higher magnification of the microvillous border shown in Figure 15. The limiting membranes of the microvilli are composed of intensely electron-dense spherical units linked by filamentous material. Longitudinally orientated chains of material similar to that which comprises the limiting membranes are present within the microvilli and extend into the clear zone. Filaments extend from the entire surface of the microvilli. The round structures (arrow) present in the microvillous border appear to arise from 'degeneration' of microvilli. A vesicle $(V)$ which contains filamentous material is in the clear zone $(\times 93,000)$. 


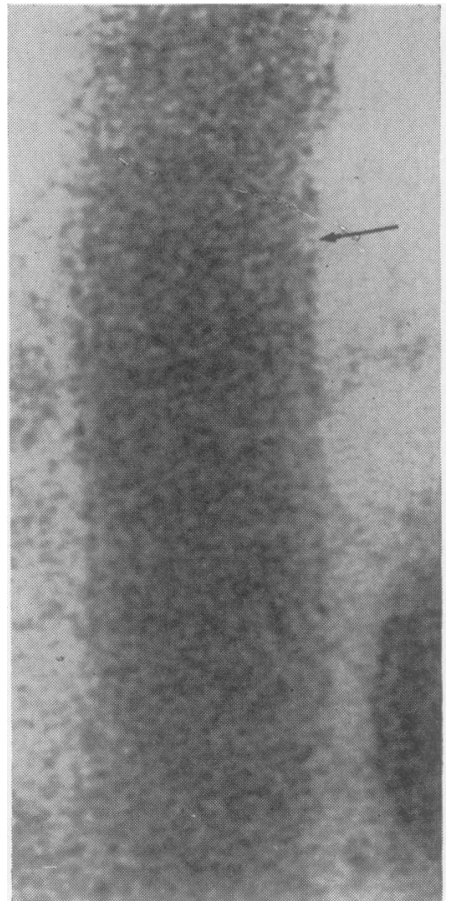

FIG. 17.

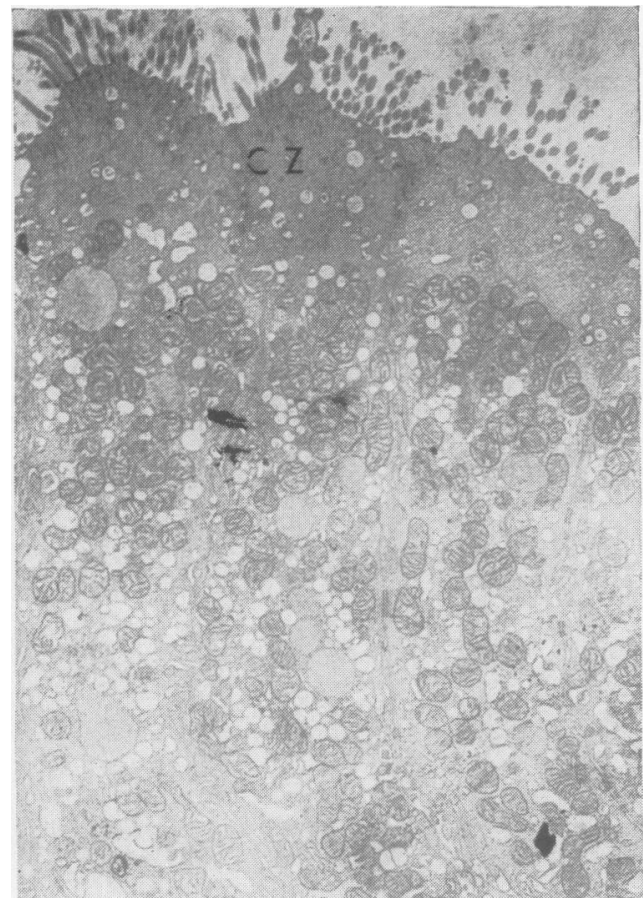

FIG. 18.

FIG. 17. High magnification of microvillus to demonstrate the spherical units and filamentous material comprising the limiting membranes. There appear to be openings (arrow) between some of the spherical units $(\times 291,500)$.

FIG. 18. Clear zone (CZ) of principal cells. Numerous vesicles are present throughout the cytoplasm of these cells $(\times 3,900)$.

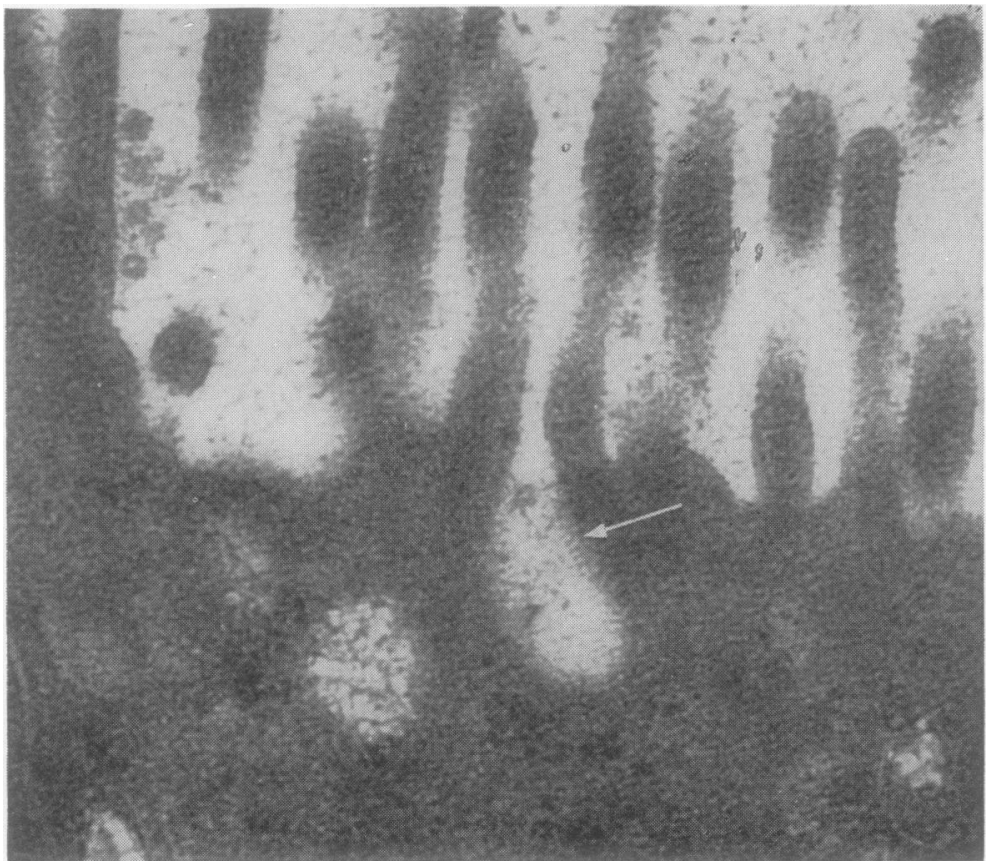

FIG. 19. A vesicle (arrow) in contact with the surface membranes between microvilli $(\times 64,800)$. 


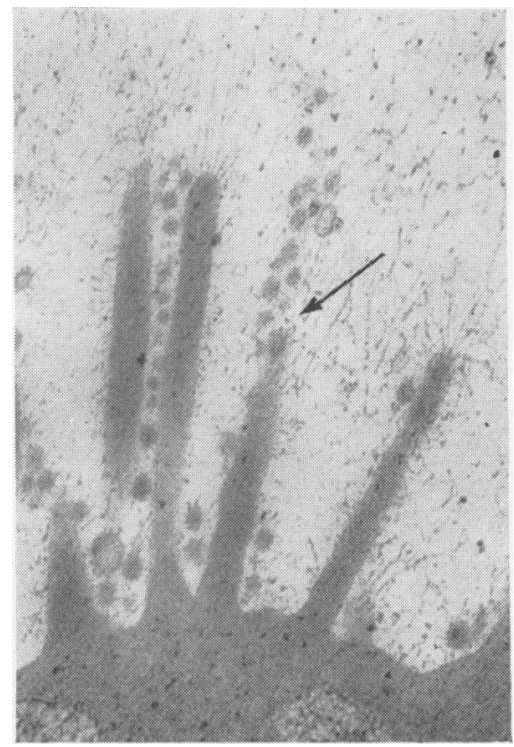

FIG. 20.

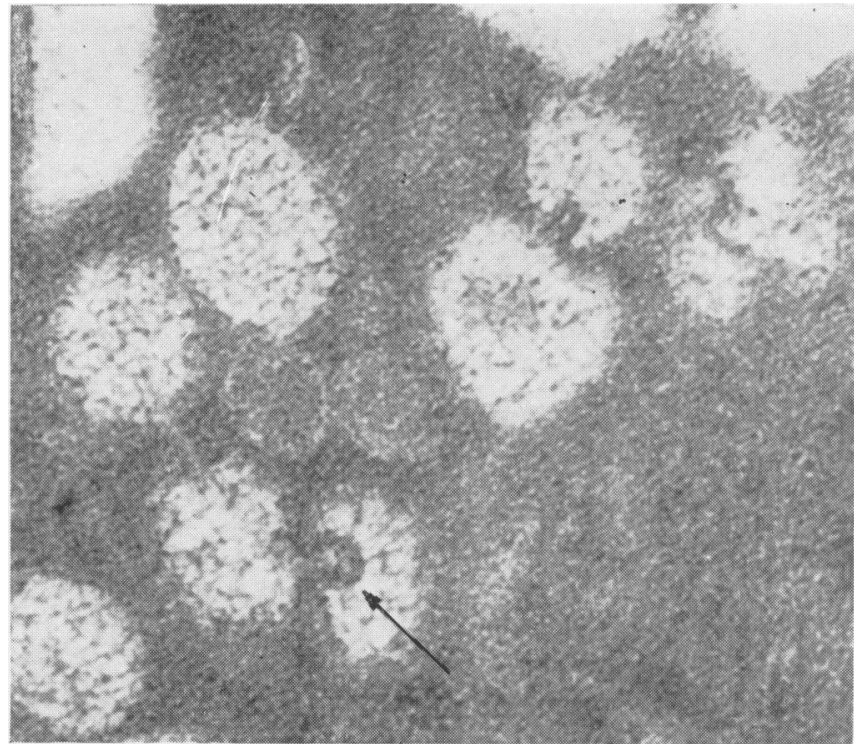

FIG. 21.

FIG. 20. Round structures in the microvillous border of a colonic mucosal principal cell. These structures appear to arise from the 'degeneration' of microvilli (arrow) $(\times 50,000)$.

FIG. 21. Vesicles which contain bodies similar to the round structures found in the microvillous border (arrow). This group of vesicles is just beneath the microvilli $(\times 64,800)$.

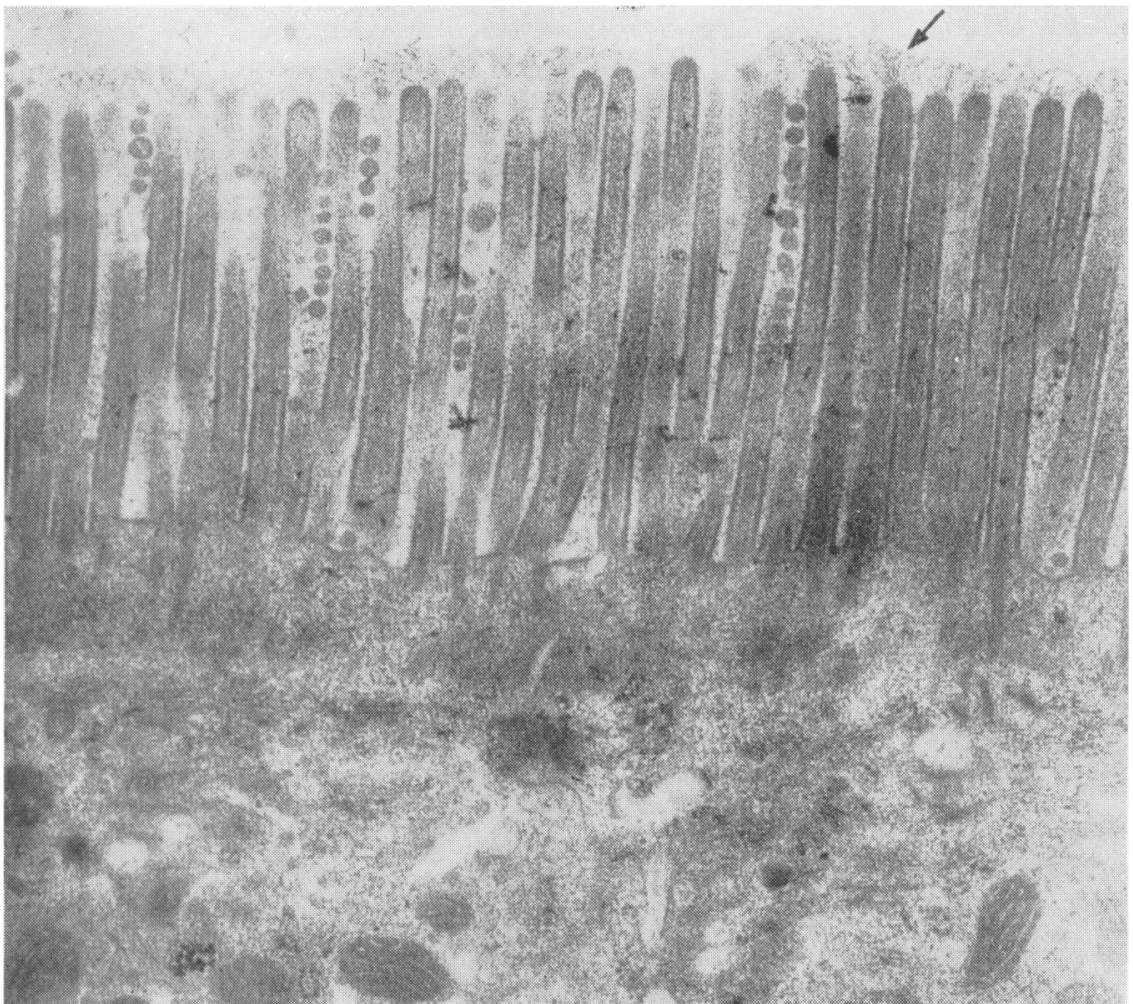

FIG. 22. Principal cell microvilli of normal human jejunal mucosa. The microvilli are covered by a filamentous coat (arrow) which is more dense than that of sigmoid colonic mucosa, but extends a shorter distance from the tips of the microvilli. Otherwise the appearance of this coat and of the filaments in the interior of the microvilli are like those of colonic mucosa. Numerous round structures are present in the microvillous border $(\times 28,800)$. 


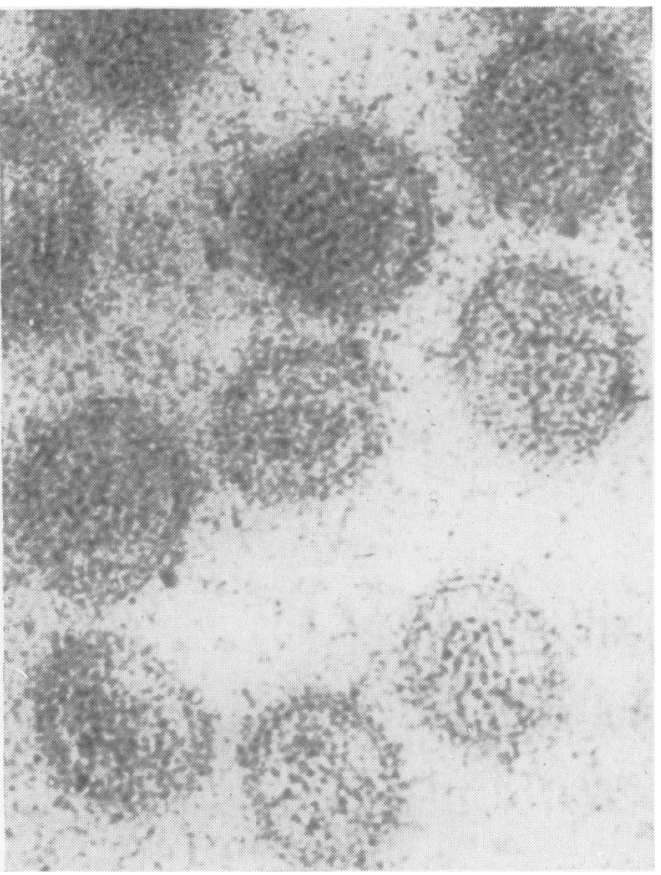

FIG. 23a.

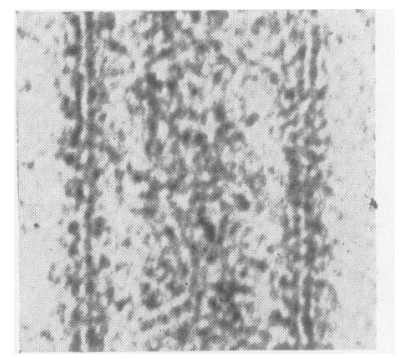

FIG. 23b.

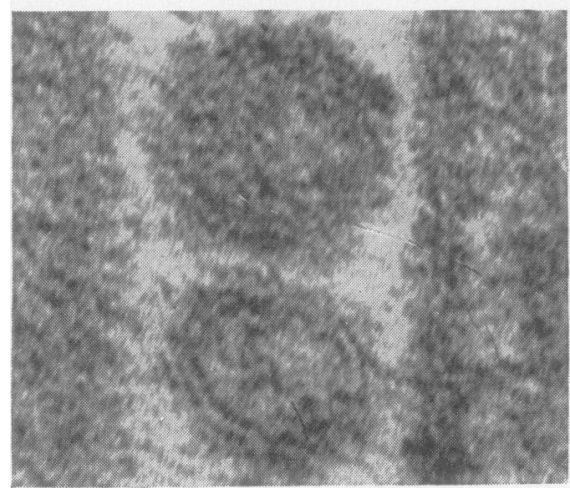

FIG. 23c.

FIG. 23a. Transverse section through normal human jejunal microvilli $(\times 160,000)$.

FIG. 23b. High magnification of normal human jejunal microvilli to show the limiting membranes composed of spherical units and filamentous material identical to those of the limiting membranes of microvilli $(\times 323,000)$.

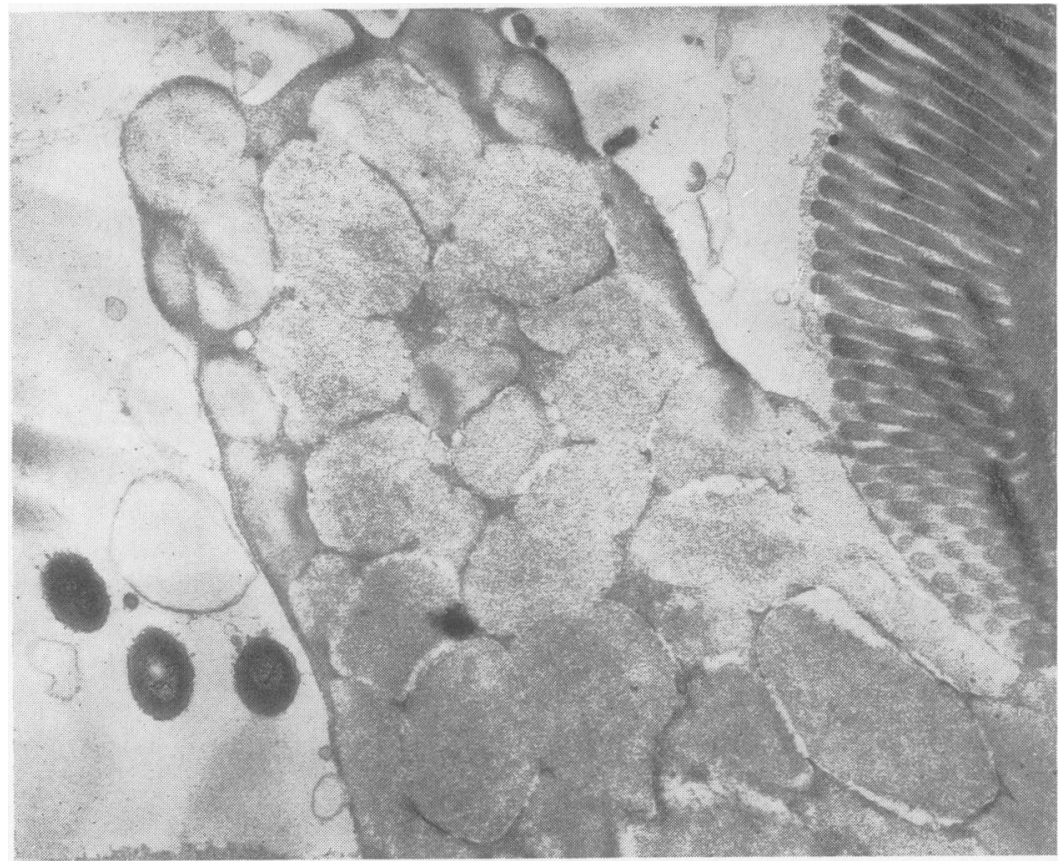

FIG. 24. Normal human jejunal mucosa. Mucin in the process of extrusion from a goblet cell. There is a striking similarity between the filamentous material in the mucin droplets and the filamentous material which covers the microvilli $(\times 15,500)$. 


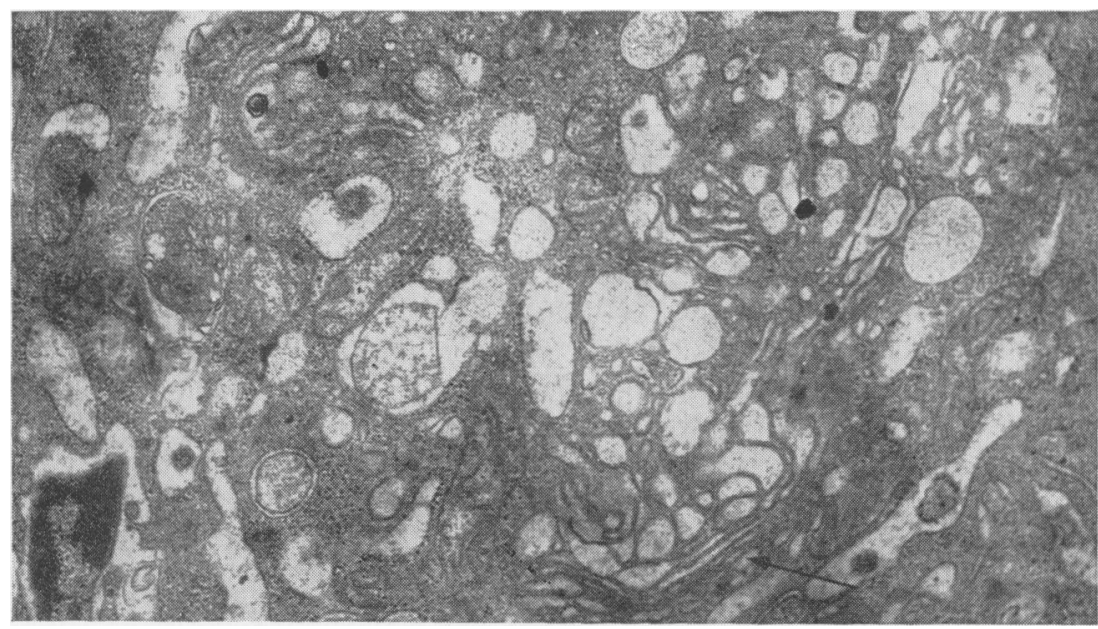

FIG. 25. Normal human sigmoid colonic mucosa.

Supranuclear Golgi membranes (arrow) and vesicules of principal cell. These vesicles also contain filaments $(\times 18,400)$.

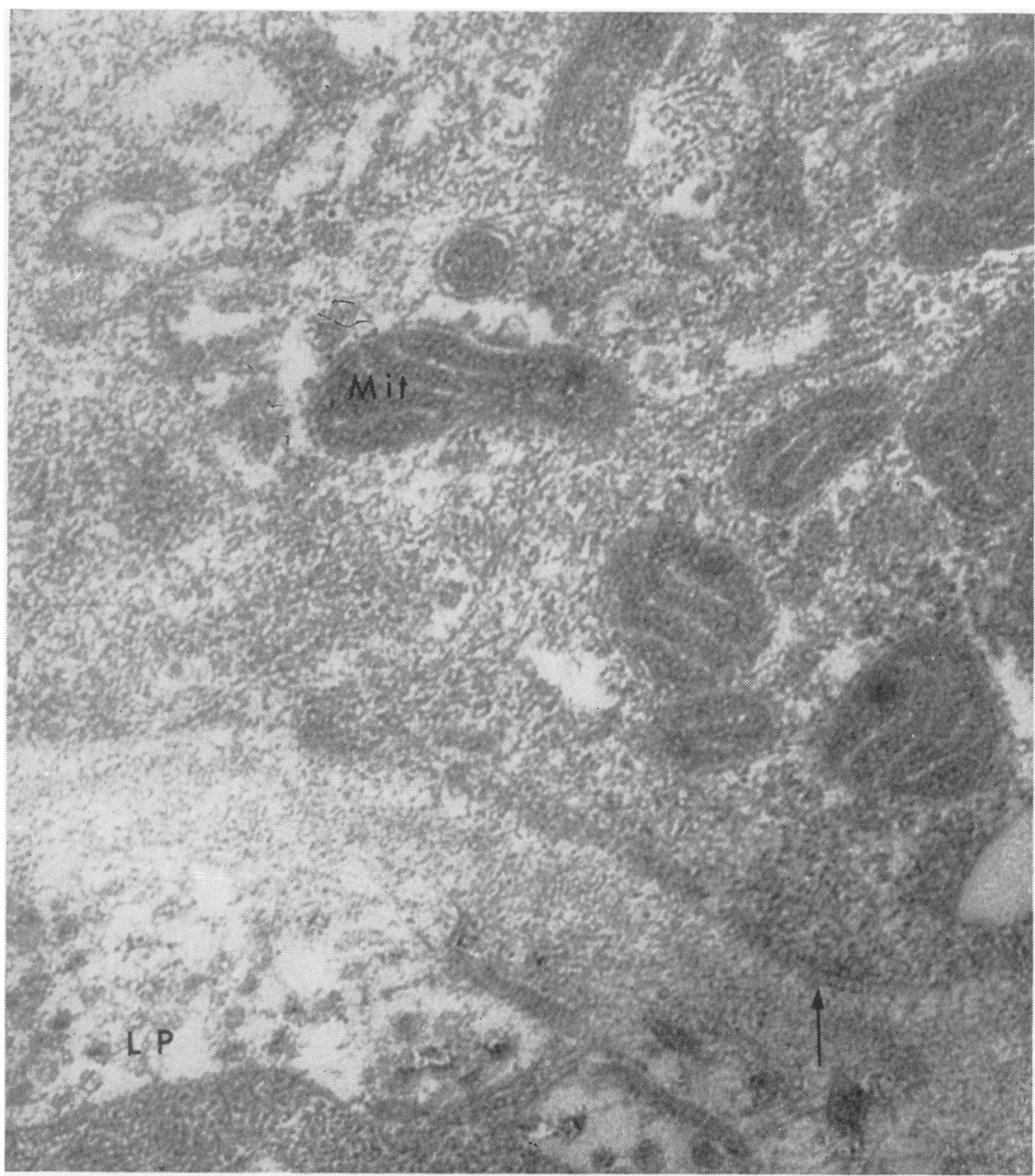

FIG. 26. High magnification of the base of a principal cell. Beneath the basilar membrane (arrow) is a network of filaments approximately $0.25 \mu$ thick $(\times 77,600)$. 


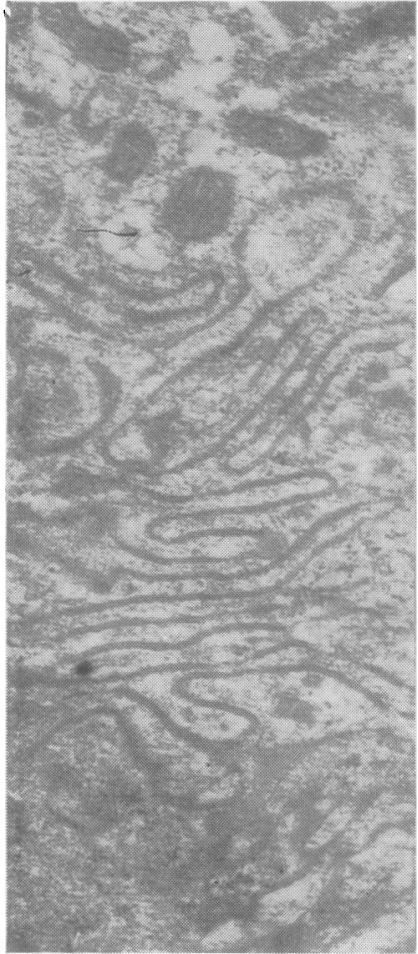

FIG. 27.

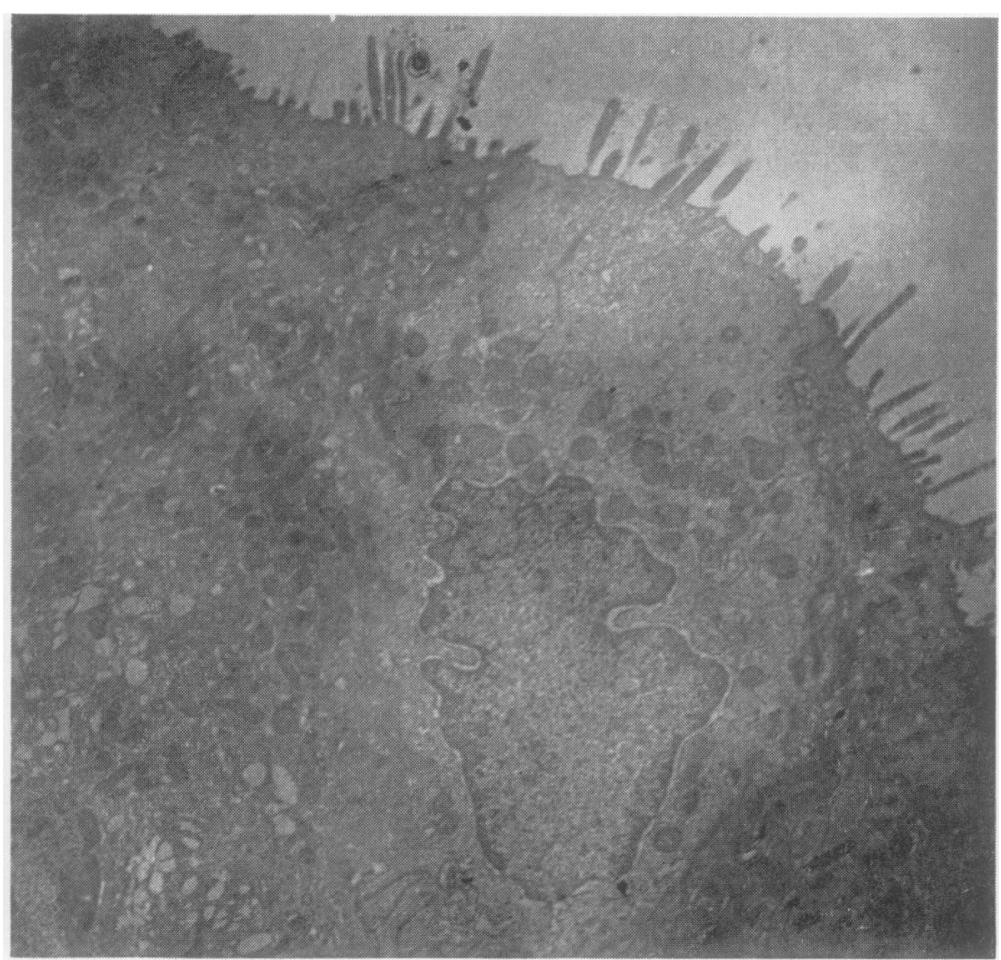

FIG. 28.

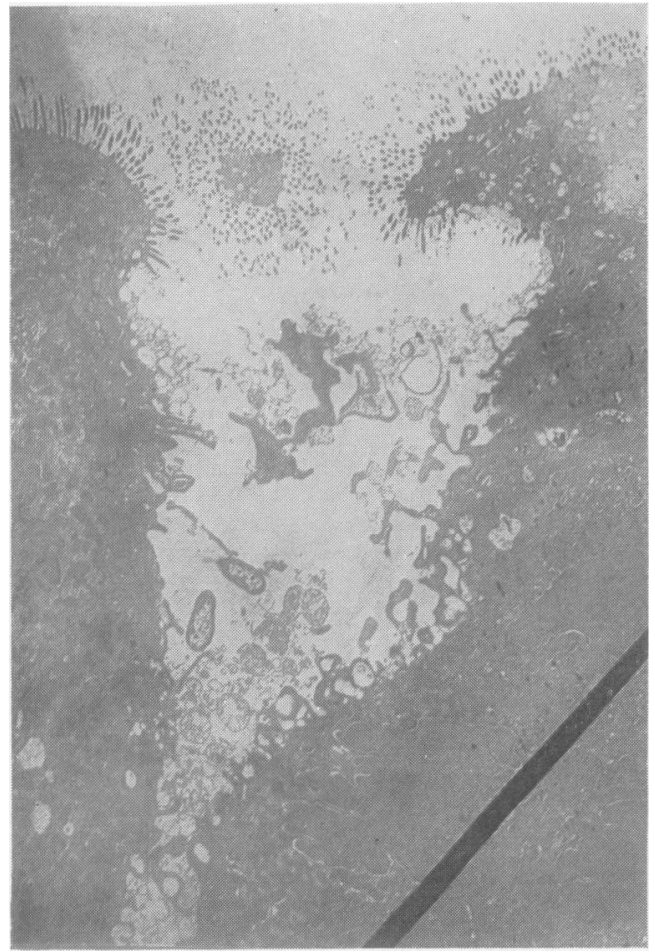

FIG. 27. Interdigitating lateral cell walls of principal cells ( $\times 24,900)$.

FIG. 28. Extrusion zone of the epithelial layer of normal human sigmoid colonic mucosa. The cytoplasm of this principal cell in the first stage of death is less electrondense than that of adjacent cells. Complete loss of microvilli and marked vesiculation of the cytoplasm occur subsequently $(\times 9,000)$.

FIG. 29. The final stage of death of a principal cell. After the dead cell is extruded, adjacent cells move together and close the gap $(\times 2,300)$.

FIG. 29. 


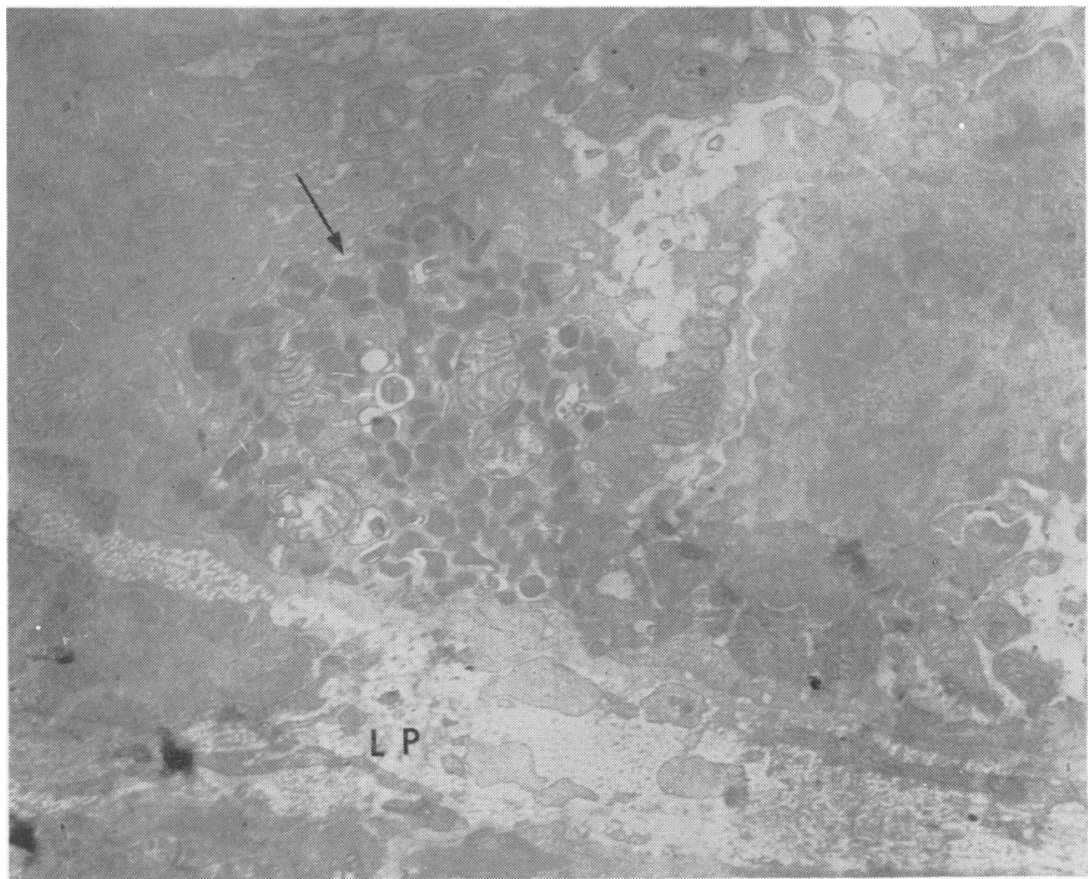

FIG. 30. A Kultschitzky cell (argentaffin or enterochromaffin cell) in the basilar portion of a crypt of Lieberkühn $(\times 11,600)$.

colonic mucosal goblet cells contain filamentous material like that found at the surface of the microvilli. Similarly, mucin droplets of jejunal mucosal goblet cells contain material which resembles the filamentous coating of jejunal microvilli (Fig. 24).

\section{TABLE I}

COMPARISON OF MICROVILLI OF PRINCIPAL CELLS OF HUMAN SIGMOID COLONIC AND JEJUNAL MUCOSA ${ }^{1}$

\begin{tabular}{|c|c|c|}
\hline & Sigmoid Colon & Jejunum \\
\hline Length of microvilli $(\mu)$ & $2 \cdot 0$ & $6 \cdot 0$ \\
\hline Width of microvilli $(\mu)$ & 0.25 & 0.40 \\
\hline Space between microvilli $(\mu)$ & 0.06 to 1.33 & 0.5 to 0.6 \\
\hline $\begin{array}{l}\text { Diameter of round structures which } \\
\text { may be formed by 'degeneration' }\end{array}$ & & \\
\hline $\begin{array}{l}\text { of microvilli }(\mu) \\
\text { Height of filamentous covering }\end{array}$ & 0.04 to 0.08 & 0.1 to 0.25 \\
\hline of microvilli $(\mu)$ & $2 \cdot 0$ & 0.5 \\
\hline $\begin{array}{l}\text { Width of space between electron-dense } \\
\text { layers of plasma membrane }(\AA)\end{array}$ & 100 & 170 \\
\hline $\begin{array}{l}\text { Diameter of highly electron-dense } \\
\text { spherical units }(\AA)\end{array}$ & 375 & 200 \\
\hline $\begin{array}{l}\text { Thickness of filamentous material } \\
\text { joining spherical units }(\AA)\end{array}$ & 190 & 100 \\
\hline
\end{tabular}

${ }^{1}$ Dimensions are approximate.

Principal cells of normal sigmoid colonic mucosa have prominent supranuclear Golgi membranes (Fig. 25). Vesicles which contain filamentous material are present in the region of the Golgi membranes. The paranuclear and basilar portions of principal cells contain alpha-cytomembranes, mitochondria, vesicles, and granular material. The basilar membrane is composed of closely approximated electrondense spherical units and beneath it is a network of filaments approximately $0.25 \mu$ thick (Fig. 26). Some of these filaments appear to traverse the basilar membrane and also to extend into the lamina propria. The lateral cell walls, whose unit structure is similar to that of the basilar membrane, interdigitate with those of adjacent cells (Fig. 27).

On the mucosal surface, approximately midway between glands, is the extrusion zone, where cells die and are expelled into the lumen of the bowel. Dying cells are characterized by decreased electron density of the cytoplasm and loss of microvilli and their filamentous covering (Fig. 28). The contents of these cells are subsequently extruded and adjacent cells move together and close the gap (Fig. 29).

KULTSCHITSKY CELLS Kultschitsky (argentaffin or enterochromaffin cells) are found occasionally in the basilar portions of crypts of Lieberkühn, and are distinguished by the presence of electron-dense bodies within their cytoplasm (Fig. 30).

No significant differences in ultrastructural appearances of colonic mucosal specimens obtained from the subjects of this study were observed. In particular, the findings were the same in those who received 'clean-out' enemas and those who did not. 
COMMENT $^{1}$

This study has revealed a prominent network of filaments extending from the surface of principal cell microvilli in normal human sigmoid colonic and jejunal mucosal epithelia. The presence of filamentous coatings on the surfaces of various cells has been demonstrated since Chambers (1940) first observed layers of organic material superficial to the plasma membrane of sea-urchin eggs. He called this material the 'extraneous coat' because it could be removed without causing immediate death of the cell. Yamada (1955) subsequently demonstrated fine filaments covering microvilli of mouse gall bladder epithelium, Pappas (1959) found that the surface membranes of amoebae are covered by numerous filamentous extensions, Peachy and Rasmussen (1961) observed a covering of filaments on the surface of the toad bladder, Ito and Winchester (1963) described a similar coating on gastric mucosal microvilli of the bat, and Rifaat, Iseri, and Gottlieb (1965) made the initial observation that a coating of filamentous material is present on microvilli of human colonic mucosal specimens. Some of these coatings were shown to be periodic acid-Schiff (P.A.S.) positive before and after incubation with diastase, an observation which suggests that they contain mucopolysaccharide. Ito (1965) recently studied intensively the filamentous coating of cat intestinal microvilli and demonstrated that the filaments react with colloidal thorium dioxide, indicating the presence of acid mucopolysaccharide (Revel, 1964). Ito also found that this coating in the cat intestine is stable during various physiological conditions and is resistant to repeated washings or incubations with mucolytic chemical agents and proteolytic and mucolytic enzymes.

The origin of the filamentous covering of mammalian microvilli is in doubt, partly because of its ultrastructural similarity to mucin. The findings of this study suggest, however, that the filaments are an integral part of the cell surface. Their close resemblance to filaments within the microvilli suggests the possibility that the coating filaments arise within microvilli and are extruded through their limiting membranes. Another possibility is that the filaments are synthesized by enzymes present in the limiting membranes themselves.

The function of the filamentous coating is also unclear. Ito (1964) suggested that it may act as a barrier to protect the cell surface from direct contact with bacteria, carbon particles, and other matter within the intestinal lumen. Brandt (1962) presented

'This discussion is limited to considerations of the possible significance of the ultrastructural organization of the surface of principal cells and of vesicles found within the cytoplasm of these cells. evidence that large molecules are bound to the filamentous coat before being taken into the cell by the process of pinocytosis. Other possibilities are that the coating contains digestive enzymes, that it has buffering capacity and acts to maintain a desirable $p \mathrm{H}$ at the locus of the absorbing membranes, that it plays a role in absorption by acting as an ionexchange vehicle, and that it is simply a coating of mucus, derived from the cell, which functions as a lubricant.

Marked vesiculation was noted in colonic mucosal principal cells, whose primary function is thought to be the absorption of water and electrolytes. Networks of filaments, similar to those which coat the surface membranes, were found within these vesicles, and it is possible that they are pinocytotic, arising either from invaginations of the surface membranes (Odor, 1956), or from the coalescence of lateral surfaces of microvilli. The filamentous material and round structures found in the microvillous border would thus he incorporated into the vesicles at the time of their formation. If the vesicles are formed in this manner continual replacement of the principal cell membranes would be required to prevent a net loss of surface area. The replacement material could be the intramicrovillous filaments which, in turn, could be synthesized in the clear zone. Such a process of pinocytosis would benefit cell economy, for 'degenerated' microvilli and filamentous material would be reincorporated into the cell rather than lost into the lumen of the bowel.

Another possibility is that the vesicles are not pinocytotic, but arise from the Golgi apparatus (Fig. 25), as do mucin droplets of goblet cells, move to the surface of the cell, and become incorporated into the cell membranes. Still another possibility is that there are both pinocytotic and secretory vesicles present in the cytoplasm.

SUMMARY

The ultrastructural appearances of epithelial cells lining sigmoid colonic mucosa obtained from 17 normal human subjects are described. The microvillous border of this epithelium is compared with that of the epithelium of normal human jejunal mucosa.

We are grateful to Dr. J. M. French and Professor W. Melville Arnott for their encouragement and support of this work, to Professor J. Sayers who kindly allowed the use of the electron microscope in the Department of Electron Physics at the University of Birmingham, to Mr. C. C. Newton who maintained the electron microscope, and to Mr. R. Stucky who assisted with the photography. Financial assistance was provided by the Endowment Fund of the United Birmingham Hospitals. One of 
us (F.E.P.) is indebted to the Helen Hay Whitney Foundation (New York, N.Y., U.S.A.) for a fellowship.

\section{REFERENCES}

Brandt, P. W. (1962). A consideration of the extraneous coats of the plasma membrane. Circulation, 26, 1075-1091.

Caulfield, J. B. (1957). Effects of varying the vehicle for $\mathrm{OsO}_{4}$ in tissue fixation. J. biophys. biochem. Cytol., 3, 827-830.

Chambers, R. (1940). The relation of the extraneous coats to the organization and permeability of cellular membranes. Cold Spr. Harb. Symp. quant. Biol., 8, 144-153.

Cole, J. W., and McKalen, A. (1961). Observations of cell renewal in human rectal mucosa in vivo with thymidine- $\mathrm{H}^{3}$. Gastroenterology, 41, 122-125.

Crosby, W. H., and Kugler, H. W. (1957). Intraluminal biopsy of the small intestine. The intestinal biopsy capsule. Amer. J. dig. Dis., 2, 236-241.

Dalton, A. J. (1951). Electron micrography of epithelial cells of the gastro-intestinal tract and pancreas. Amer. J. Anat., 89, 109-133.

Flick, A. L., Voegtlin, K. F., and Rubin, C. E. (1962). Clinical experience with suction biopsy of the rectal mucosa. Gastroentero$\log y, 42,691-705$.

Florey, H. W. (1960). Electron microscopic observations on goblet cells of the rat's colon. Quart. J. exp. Physiol., 45, 329-336.

Freeman, J. A. (1562). Fine structure of the goblet cell mucous secretory process. Anat. Rec., 144, 341-345.

Hampton, J. C. (1960). An electron microscopic study of mouse colon. Dis. Colon Rect., 3, 423-440.

Hayward, A. F., and Johnston, H. S. (1961). The fine structure of the epithelium of the colon in the mouse. Scot. med. J., 6, 416-425.

Hollmann, K. H. (1963). The fine structure of the goblet cells in the rat intestine. Ann. N.Y. Acad. Sci., 106, 545-554.

Ito, $S$. (1965). The enteric surface coat on cat intestinal microvilli. J. Cell Biol., 27, 475-491.

- (1S64). The surface coating of enteric microvilli. (Abstr.) Anat. Rec., 148, 294.

$\longrightarrow$, and Winchester, R. J. (1963). The fine structure of the gastric mucosa in the bat. J. Cell Biol., 16, 541-577.

Lane, N., Caro, L., Otero-Vilardebó, L. R., and Godman, G. C. (1964). On the site of sulfation in colonic goblet cells. Ibid., 21, 339-351.

Lipkin, M., Sherlock, P., and Bell, B. (1963). Cell proliferation kinetics in the gastrointestinal tract of man. II. Cell renewal in stomach, ilieum, colon, and rectum. Gastroenterology, 45, 721-729.

Lockwood, W. R. (1964). A reliable and easily sectioned epoxy embedding medium. Anat. Rec., 150, 129-140.
MacDonald, W. C., Trier, J. S., and Everett, N. B. (1964). Cell proliferation and migration in the stomach, duodenum, and rectum of man: radioautographic studies. Gastroenterology, 46, 405-417.

Millonig, G. (1961). A modified procedure for lead staining of thin sections. J. biophys. biochem. Cytol., 11, 736-739.

Moses, M. J. (1964). The nucleus and chromosomes: a cytological perspective. In Cytology and Cell Physiology, edited by G. H. Bourne, 3rd ed., pp. 423-558. Academic Press, New York and London.

Odor, D. L. (1956). Uptake and transfer of particulate matter from the peritoneal cavity of the rat. J. biophys. biochem. Cytol., 2, (suppl.), 105-108.

Palade, G. E. (1958). A small particulate component of the cytoplasm. In Frontiers in Cytology, edited by S. L. Palay, pp. 283-304. Yale Univ. Press, New Haven.

Pappas, G. D. (1959). Electron microscope studies on amoebae. Ann. N.Y. Acad. Sci., 78, 448-473.

Peachey, L. D., and Rasmussen, H. (1961). Structure of the toad's urinary bladder as related to its physiology. J. biophys. biochem. Cytol., 10, 529-553.

Pittman, F. E., and Pittman, J. C. (1966). Electron microscopy of intestinal mucosa: some notes on techniques. Arch. Path., 81, 398-401.

Rangan, S. R. S. (1961). A method of orientation of biological specimens for electron microscopy. J. roy. micr. Soc., 79, 377-378.

Revel, J. P. (1964). A stain for the ultrastructural localization of acid mucopolysaccharides. J. Micr., 3, 535-544.

Rifaat, M. K., Iseri, O. A., and Gottlieb, L. S. (1965). An ultrastructural study of the 'extraneous coat' of human colonic mucosa. Gastroenterology, 48, 593-601.

Sabatini, D. D., Bensch, K., and Barrnett, R. J. (1963). Cytochemistry and electron microscopy. The preservation of cellular ultrastructure and enzymatic activity by aldehyde fixation. $J$. Cell Biol., 17, 19-58.

Shearman, D. J. C., and Muir, A. R. (1960). Observations on the secretory cycle of goblet cells. Quart. J. exp. Physiol., 45, 337-342.

Sjöstrand, F. S. (1964). The endoplasmic reticulum. In Cytology and Cell Physiology, edited by G. H. Bourne, 3rd ed., pp. 311-375, Academic Press, New York and London.

Trump, B. F., Smuckler, E. A., and Benditt, E. P. (1961). A method for staining epoxy sections for light microscopy. J. Ultrastruct. Res., 5, 343-348.

Wischnitzer, S. (1960). The ultrastructure of the nucleus and nucleocytoplasmic relations. Int. Rev. Cytol., 10, 137-162.

Yamada, E. (1955). The fine structure of the gall bladder epithelium of the mouse. J. biophys. biochem. Cytol., 1, 445-458. 